
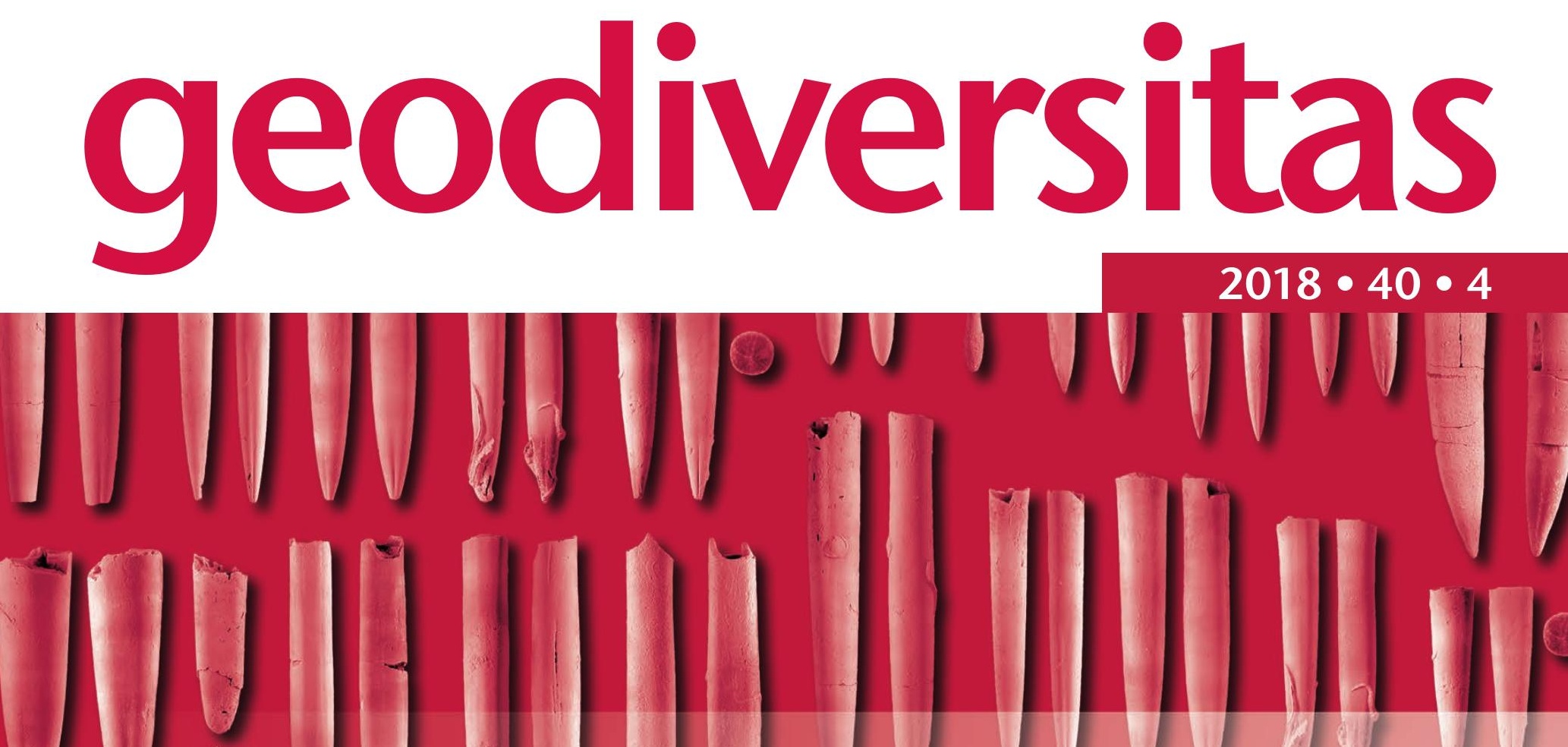

Lower Jurassic ( $P \mid j e n s b a c h i a n-T o a r c i a n)$ belemnites (6) from Fresney-le,Puceux (Calvados, france): taxonomy, chronostratigraphy and diversity
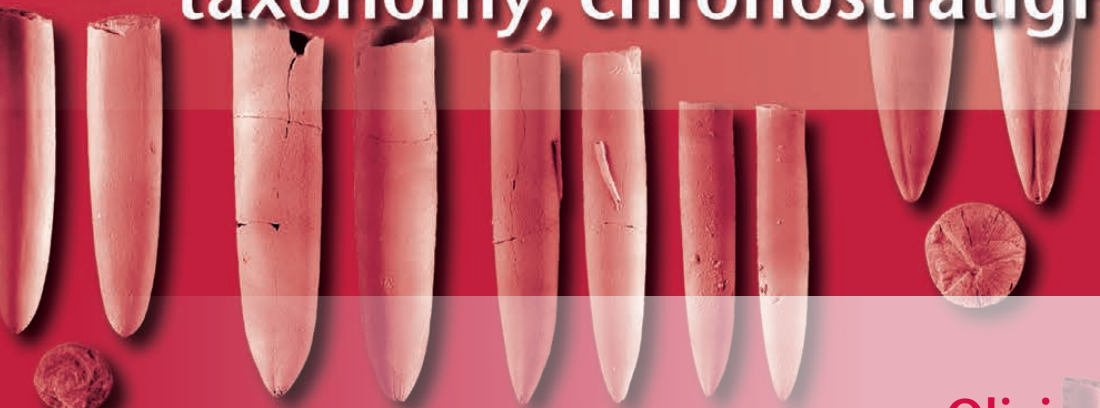

Robert WEIS, Pascal NEIGE, Olivier DUGUÉ, Andrea DI CENCIO,
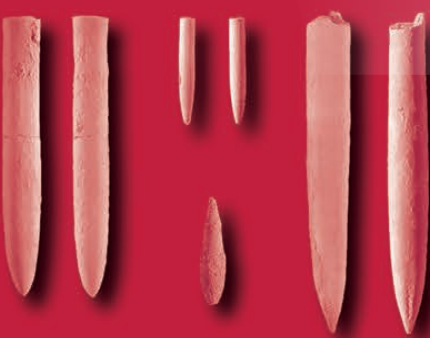

Ben THUY, Lea NUMBERGER-THUY \& Nino MARIOTTI
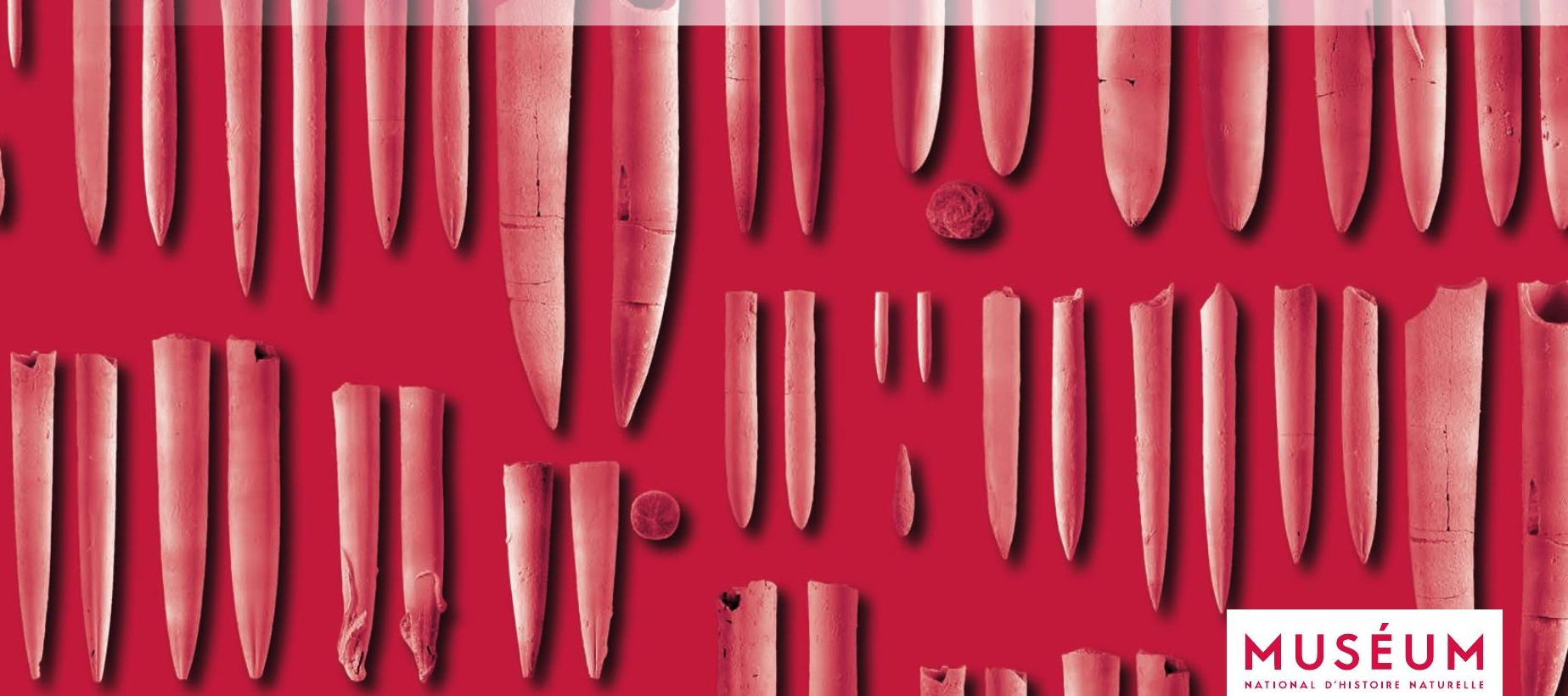
DiRECTEUR DE LA PUblication: Bruno David,

Président du Muséum national d'Histoire naturelle

RÉdACTEUR EN CHEF / EDITOR-IN-CHIEF: Didier Merle

ASSISTANTS DE RÉDACTION / AsSISTANT EDITORS: Emmanuel Côtez (geodiv@mnhn.fr); Anne Mabille

Mise en PAge / PAGE LAYOUt: Emmanuel Côtez

COMITÉ SCIENTIFIQUE / SCIENTIFIC BOARD:

Christine Argot (MNHN, Paris)

Beatrix Azanza (Museo Nacional de Ciencias Naturales, Madrid)

Raymond L. Bernor (Howard University, Washington DC)

Alain Blieck (USTL, Villeneuve d'Ascq)

Henning Blom (Uppsala University)

Jean Broutin (UPMC, Paris)

Gaël Clément (MNHN, Paris)

Ted Daeschler (Academy of Natural Sciences, Philadelphie)

Bruno David (MNHN, Paris)

Gregory D. Edgecombe (The Natural History Museum, Londres)

Ursula Göhlich (Natural History Museum Vienna)

Jin Meng (American Museum of Natural History, New York)

Brigitte Meyer-Berthaud (CIRAD, Montpellier)

Zhu Min (Chinese Academy of Sciences, Pékin)

Isabelle Rouget (UPMC, Paris)

Sevket Sen (MNHN, Paris)

Stanislav Štamberg (Museum of Eastern Bohemia, Hradec Králové)

Paul Taylor (The Natural History Museum, Londres)

COUVERTURE / COVER:

Réalisée à partir des Figure 10 et 11 de cet article/created from Figures 10 and 11 of this article

Geodiversitas est indexé dans / Geodiversitas is indexed in:

- Science Citation Index Expanded (SciSearch ${ }^{\circledR}$ )

- ISI Alerting Services ${ }^{\circledR}$

- Current Contents ${ }^{\circledR}$ / Physical, Chemical, and Earth Sciences ${ }^{\circledR}$

- Scopus ${ }^{\circledR}$

Geodiversitas est distribué en version électronique par / Geodiversitas is distributed electronically by:

- BioOne ${ }^{\circledR}$ (http://www.bioone.org)

Les articles ainsi que les nouveautés nomenclaturales publiés dans Geodiversitas sont référencés par / Articles and nomenclatural novelties published in Geodiversitas are referenced by:

- ZooBank ${ }^{\circledR}$ (http://zoobank.org)

Geodiversitas est une revue en flux continu publiée par les Publications scientifiques du Muséum, Paris Geodiversitas is a fast track journal published by the Museum Science Press, Paris

Les Publications scientifiques du Muséum publient aussi / The Museum Science Press also publish: Adansonia, Zoosystema, Anthropozoologica, European Journal of Taxonomy, Naturae.

Diffusion - Publications scientifiques Muséum national d'Histoire naturelle

CP $41-57$ rue Cuvier F-75231 Paris cedex 05 (France)

Tél.: 33 (0)1 40794805 / Fax: 33 (0)1 40793840

diff.pub@mnhn.fr / http://sciencepress.mnhn.fr

(C) Publications scientifiques du Muséum national d'Histoire naturelle, Paris, 2018

ISSN (imprimé / print): 1280-9659/ ISSN (électronique / electronic): 1638-9395 


\title{
Lower Jurassic (Pliensbachian-Toarcian) belemnites from Fresney-le-Puceux (Calvados, France): taxonomy, chronostratigraphy and diversity
}

\author{
Robert WEIS \\ Musée national d'histoire naturelle de Luxembourg, section Paléontologie \\ 25 rue Münster, L-2160 Luxembourg (Grand-duché de Luxembourg) \\ rweis@mnhn.lu \\ Pascal NEIGE \\ Université Bourgogne Franche-Comté, CNRS, Biogéosciences \\ 6 boulevard Gabriel, F-21000, Dijon (France) \\ pascal.neige@u-bourgogne.fr \\ Olivier DUGUÉ \\ Université Caen-Normandie, UMR CNRS 6143 M2C \\ 24 avenue des Tilleuls, F-14000 Caen (France) \\ olivier.dugue@unicaen.fr \\ Andrea DI CENCIO \\ Ben THUY \\ Lea NUMBERGER-THUY \\ Musée national d'histoire naturelle de Luxembourg, section Paléontologie \\ 25 rue Münster, L-2160 Luxembourg (Grand-duché de Luxembourg) \\ andreadicencio@geologiaepaleontologia.eu \\ bthuy@mnhn.lu \\ Inumberger@gmx.de
}

Nino MARIOTTI

Musée national d'histoire naturelle de Luxembourg, section Paléontologie

25 rue Münster, L-2160 Luxembourg (Grand-duché de Luxembourg) and Università 'La Sapienza', Dipartimento di Scienze della Terra

Piazzale A. Moro 5, I-00185 Roma (Italia) nino.mariotti@uniroma1.it

Submitted on 12 May 2017 | accepted on 3 October 2017 | published on 1 March 2018

urn:Isid:zoobank.org:pub:1B9774F9-1B39-446A-BD3C-2DEC49993C83

Weis R., Neige P., Dugué O., Di Cencio A., Thuy B., Numberger-Thuy L. \& Mariotti N. 2018. - Lower Jurassic (Pliensbachian-Toarcian) belemnites from Fresney-le-Puceux (Calvados, France): taxonomy, chronostratigraphy and diversity. Geodiversitas 40 (4): 87-113. https://doi.org/10.5252/geodiversitas2018v40a4. http://geodiversitas.com/40/4

KEY WORDS

Belemnites,

ammonites,

cephalopods,

stratigraphy,

stratigraphy,
Pliensbachian,

Toarcian,

la Roche Blain quarry,

Normandy.

\section{ABSTRACT}

The present paper deals with the systematic description of the belemnite assemblages from the Lower Jurassic, collected at the Roche Blain quarry, Fresney-le-Puceux. In spite of the reduced thickness of the succession at Fresney-le-Puceux, 13 successive ammonite chronozones could be documented in this rather unique outcrop situation in mainland Europe. Twelve genera and 26 species of belemnites belonging to the Passaloteuthididae, Hastitidae, Megateuthididae, Salpingoteuthididae, and family 


MOTS CLÉS
Bélemnites,
ammonites,
céphalopodes,
stratigraphie,
Pliensbachien,
Toarcien,
carrière la Roche Blain,
Normandie.

MOTS CLÉS

ammonites,

shalopodes,

Piensbachien,

oche Blain,

Normandie. incertae sedis are described and illustrated herein. The stratigraphical range of the belemnites is correlated with the standard ammonite zonation, using the chronozone concept: the described specimens range from the lower Pliensbachian (Davoei Chronozone) to the uppermost Toarcian (Aalensis Chronozone) while ammonites indicate the Aalenian (Murchisonae Chronozone) to be present too, but these beds delivered no identifiable belemnites so far. The belemnite diversity from Normandy is compared to data from coeval outcrops in Western and Central Europe.

\section{RÉSUMÉ}

Bélemnites du Jurassique inférieur (Pliensbachien-Toarcien) de Fresney-le-Puceux (Calvados, France): taxonomie, chronostratigraphie et diversité.

Cet article traite de la systématique des bélemnites du Jurassique inférieur récoltées dans la carrière de la Roche Blain à Fresney-le-Puceux. Malgré l'épaisseur réduite de la succession de Fresney-le-Puceux, 13 chronozones successives d'ammonites ont été documentées dans cet affleurement assez unique en Europe continentale. Douze genres et 26 espèces de bélemnites appartenant aux Passaloteuthididae, aux Hastitidae, aux Megateuthididae et aux Salpingoteuthididae, ainsi qu'à une famille incertae sedis, sont décrits et illustrés ici. L'extension stratigraphique des bélemnites est corrélée avec la zonation standard des ammonites en utilisant le concept de chronozone: les spécimens décrits s'étendent du Pliensbachien (Chronozone à Davoei) au Toarcien supérieur (Chronozone à Aalensis), tandis que les ammonites indiquent que l'Aalénien (Chronozone à Murchisonae) pourrait être présent, mais ces niveaux n’ont pas livré de bélemnites identifiables jusqu’ici. La diversité des bélemnites de Normandie est comparée à celle d'affleurements équivalents en Europe occidentale et centrale.

\section{INTRODUCTION}

The Jurassic outcrops of Normandy have been considered as reference sections for many palaeontological studies since the earliest $19^{\text {th }}$ century, mainly for the abundance and good preservation of their fossils. Especially the Middle Jurassic outcrops have received worldwide attention classically encompassing the stratotype of the Bajocian stage, located nowadays along the coast of Bayeux, at Sainte Honorine-des-Pertes (Rioult 1964, 1971; Dugué et al. 1998). The Lower Jurassic outcrops have been intensively studied mostly during the 19th century, especially for their rich and well-preserved invertebrate faunas (e.g. Eudes-Deslongchamps 1865; Caumont 1849, d'Orbigny 1842-1851). Cephalopods are generally abundant in the fossil assemblages; thus, it is not surprising to note that belemnites from Normandy are present in most historical collections in France. However, despite their abundance, they gained little attention but for Eudes-Deslongchamps (1865), d'Orbigny (1842-1851), and Lissajous (1927). Only recently, Weis et al. (2015a) described a new belemnite genus, Lissajousibelus Weis in Weis, Dzyuba, Mariotti \& Chesnier, 2015 from the Toarcian of Feuguerollessur-Orne. However, a more comprehensive study of the Lower Jurassic belemnites of Normandy lacked so far. It is the purpose of our work to report the diversity of the Pliensbachian-Toarcian belemnites and document their stratigraphical ranges.

\section{GEOLOGICAL, PALAEOBIOGEOGRAPHIC AND LITHOSTRATIGRAPHICAL SETTING}

Herein we study the section of the Roche Blain quarry near Fresney-le-Puceux, south of Caen (Normandy, France), where
Jurassic outcrops are exposed (Fig. 1), visible as a Jurassic marine transgression event on the Brioverian basement (Upper Proterozoic). Here, Jurassic rocks range from the Pliensbachian to the Aalenian. The section has been studied previously by several authors (Rioult 1968; Dugué et al. 1998; Vernhet et al. 2002) and a detailed study of Pliensbachian ammonites, including a precise biostratigraphic framework, has been published recently by Dommergues et al. (2008).

Recent field work in the quarry allowed the authors of this study to collect bed-by-bed Pliensbachian, Toarcian, and Aalenian ammonites and belemnites. Cephalopods are among the most abundant macrofossils in the marly and calcareous beds of the section, other taxa occur more rarely (echinoderms, other molluscs, brachiopods, etc). Although our focus is on the Toarcian and Aalenian stages, some newly collected Pliensbachian ammonites are also figured, adding to the chronostratigraphic framework of Dommergues et al. (2008). During the Early Jurassic, the Normandy area corresponded to a complex marine system where local reliefs were abundant, sometimes acting as reefs (Fig. 2). However, the succession at the Roche Blain quarry does not show any of these reefs. Here its base consists of transgressive sandstones (erosion of the Armorican exposed land), dated as early Pliensbachian, discordantly overlying the Brioverian basement, succeeded by fossil-rich marly and calcareous sediments. The latter sediments were deposited in slightly deeper and less turbulent marine settings between the Palaeozoic synclines of May in the north and Urville in the south (see Dommergues et al. 2008: fig. 2). Here, the Jurassic succession is approximately $9 \mathrm{~m}$ thick.

The Pliensbachian to Toarcian succession of the Roche Blain quarry is divided into four geological formations (Fm) comprising seven members (Mb) (Table 1). 


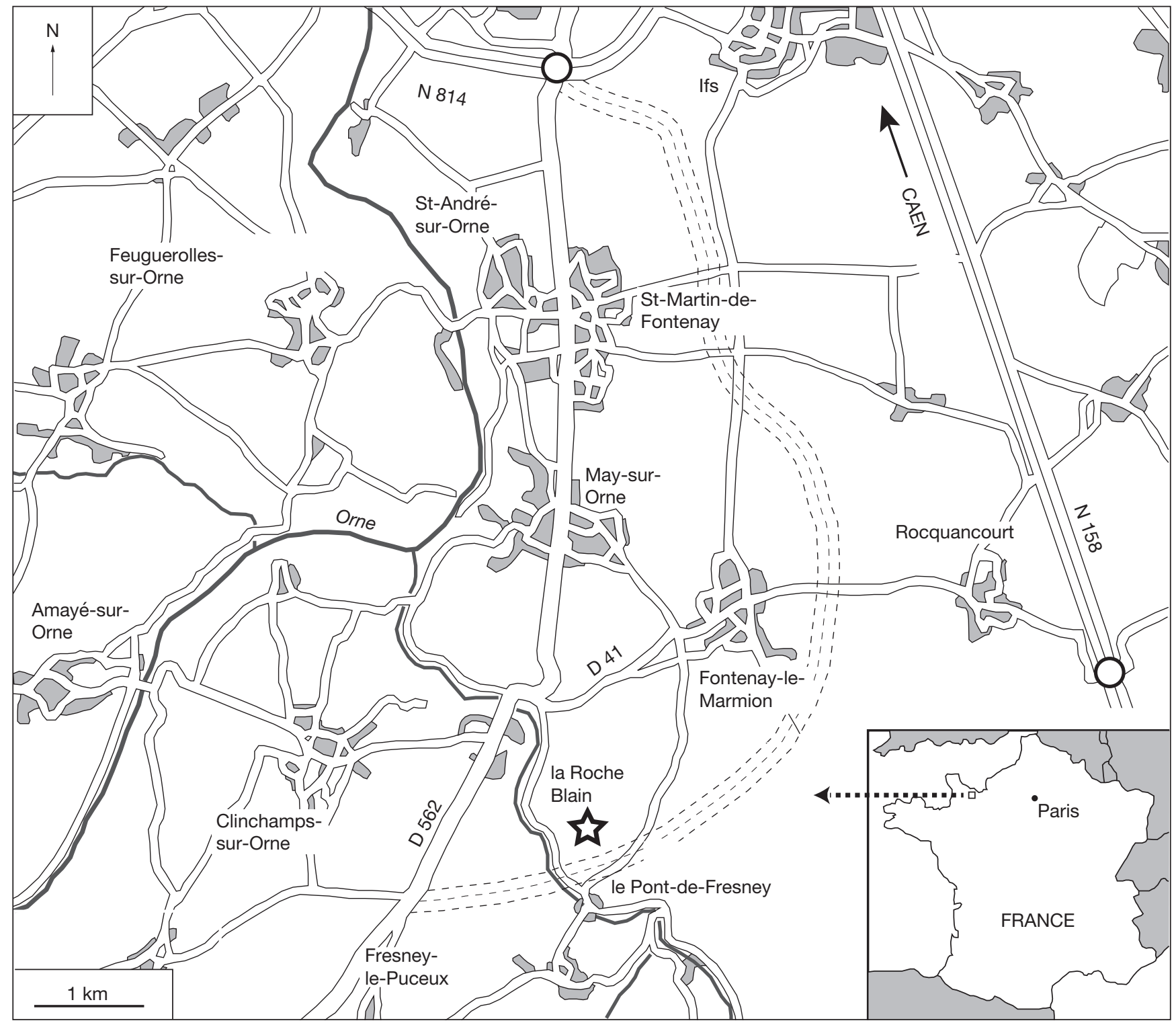

FIG. 1. - Geographical setting of the Roche Blain quarry (Normandy, France); modified after Dommergues et al. 2008.

TABLE 1. - Lithostratigraphical subdivision of the studied outcrop.

\begin{tabular}{|c|c|c|c|c|}
\hline Formations (Fm) & & Members (Mb) & & Age \\
\hline \multirow[t]{4}{*}{ Calcaire à ammonites } & \multirow[t]{4}{*}{ $\pm 2.7 \mathrm{~m}$} & Calcaire à grains ferrugineux & $0.8 \mathrm{~m}$ & Upper Toarcian \\
\hline & & Calcaire à Grammoceras & $1.6 \mathrm{~m}$ & Upper Toarcian \\
\hline & & Marnes à Haugia & $0.3 \mathrm{~m}$ & Upper Toarcian \\
\hline & & Calcaires et marnes à Hildoceras & $0.8 \mathrm{~m}$ & Lower Toarcian \\
\hline Argiles à poissons & $0.3 \mathrm{~m}$ & - & - & Lower Toarcian \\
\hline Couche à Tenuicostatum & $0.2 \mathrm{~m}$ & - & - & Lower Toarcian \\
\hline \multirow[t]{3}{*}{ Calcaire à bélemnites } & \multirow[t]{3}{*}{ $\pm 6.8 \mathrm{~m}$} & Banc de Roc & $1.7 \mathrm{~m}$ & Upper Pliensbachian \\
\hline & & Marnes à bélemnites & $0.5 \mathrm{~m}$ & Lower-upper Pliensbachian \\
\hline & & Calcaire à Cincta numismalis & $4.6 \mathrm{~m}$ & Lower Pliensbachian \\
\hline
\end{tabular}


THE “CALCAIRE À BÉLEMNITES” FM

\section{The "Calcaire à Cincta numismalis" $M b$}

At the contact with the Brioverian basement, the first Jurassic deposits are detrital, with fining upward sequences of conglomerates to sandstones (mainly consisting of rworked Triassic sediments), gradually passing upwards into clayey sandstones with belemnites and bivalves, passing upwards into densely bioturbated, bioclastic marl-limestone alternations, with ferruginous pelletoids. The thickness of the marly interbeds decreases upwards in favour of the calcareous banks. In the Bessin area west of the Fresneyle-Puceux section, this member thickens towards the west (Bessin), with more marl-limestone alternations (8 to $10 \mathrm{~m}$ ). However, to the SW of Caen, and beyond the Palaeozoic paleorelief, these alternations reach a thickness of 2.5 to $4.5 \mathrm{~m}$ and are more calcareous and bioclastic, while in the vicinity of the Palaeozoic palaeorelief, they become a crinoidal limestone.

\section{The "Marnes à bélemnites" $M b$}

This member consists of blackish pyrite-rich and bioclastic marls, with abundant belemnites and bioturbation, upwards becoming richer in small ferruginous peloids. These marls are intersected by beds of flattened clayey calcareous nodules bioturbated by Chondrites and Planolites ichnofossils. This member is thick around Bayeux, but decreases in thickness towards the SW of Caen where it was deposited between the Palaeozoic paleoreliefs (e.g. at the Roche Blain quarry), and laterally grades into bioclastic limestones with belemnites above the Palaeozoic palaeorelief of the May's syncline, eventually disappearing towards the south.

\section{The "banc de Roc" $M b$}

This member is a key regional lithological unit, which has been used as marker bed in the field. In the Fresney-lePuceux quarry, at the base stacked decimetric bioturbated biomicrites occur, rich in belemnites and ferruginous oolites. These calcareous beds are separated by thin marly layers and become amalgamated upwards, with irregular and partly stylolithic boundary surfaces. To the SW and S of Caen, and beyond the Palaeozoic palaeorelief, the limestones are intensely bioturbated and rich in ferruginous peloids. Over the palaeorelief, the marly interbeds disappear. The upper erosional surface of the "banc de Roc" Mb is overlain by a thin marly interbed that grades upwards into a bioturbated micritic limestone (biopelmicrite), with rare belemnites and ammonites ("Couche à Tenuicostatum" Fm).

\section{The “Couche À Tenuicostatum" FM}

Consists of condensed carbonates, with ferrugineous peloids, deposited in vertical continuity with the "banc de Roc", beyond the palaeoreliefs. The facies of the "Couche à Tenuicostatum" Fm is quite similar both in terms of lithology and sedimentology with the underlying "banc de Roc" $\mathrm{Mb}$. On the contrary, above this Formation, a significant sedimentary change appears ("Argiles à poissons" Fm, see below).
THE “ARGILES À POISSONS" FM

Consists of grey, bioturbated marls, with ferruginous oolites, rich in belemnites and ammonites, and including centimetrescale bioturbated nodular micritic limestone beds. In the vicinity of Caen, the "Argiles à poissons" Fm is only recognised beyond the Palaeozoic palaeorelief. To the SW of Caen (Bes$\sin$ ), it is represented by the typical laminated (bituminous) facies, with calcareous nodules. These bituminous facies are absent in the Roche Blain section. Near the Palaeozoic palaeorelief, the thickness of this formation decreases and includes abundant ferruginous peloids.

\section{THE “CALCAIRE À AMMONITES” FM \\ The "Calcaires et marnes à Hildoceras" $M b$}

This member is a clayey limestone with a very irregular lower surface, surmounted by a stromatolitic pavement. The uppermost part is characterised by amalgamated, decimetric thick bioclastic calcareous beds, with scattered ferruginous oolites and small ferruginous oncoliths. This member is thick in the Cotentin and Bessin area (6-8 m), but thins towards the Caen district, even disappearing above some Palaeozoic palaeorelief and towards Falaise (Rioult 1980). On the Palaeozoic palaeorelief of the May syncline (Feuguerolles) and in the nearby Roche Blain quarry, the first beds are encrusted with calcareous stromatolites.

\section{The "Marnes à Haugia" Mb}

This member is characterised by bioturbated grey marls with ferruginous oolites, and clayey calcareous nodules. Now the terrigenous facies appears both on the Palaeozoic palaeorelief and beyond, corresponding to a new transgressive incursion, expressed as bioturbated marls, containing abundant phosphatised ammonites.

\section{The "Calcaire à Grammoceras" $M b$}

This member consists of an alternation of marls and micritic limestones, with ferruginous oolites.

\section{The "Calcaire à grains ferrugineux" $M b$}

This member is a condensed limestone with phosphatised ammonites and ferruginous oolites. It is overlain by an erosional surface and covered by the "Marnes à ammonites" $\mathrm{Mb}$ which has a lateral lenticular form. The "Calcaire à ammonites" Fm is locally truncated by the Aalenian "Oolithe ferrugineuse" Fm, a condensed lenticular deposit (0.2 to $0.8 \mathrm{~m}$ ), including small ferruginous oolites. It is exposed from Cotentin to Bessin, in the Caen district, and at Falaise, but it is absent around Le Havre and to the south of the Falaise massif (Rioult 1980).

\section{CHRONOSTRATIGRAPHY}

The investigated section yielded several stratigraphically important ammonites (cf. Dommergues et al. 1997; Elmi et al. 1997; Page 2003), of which some were not previously mentioned by Dommergues et al. (2008), substantiating and 


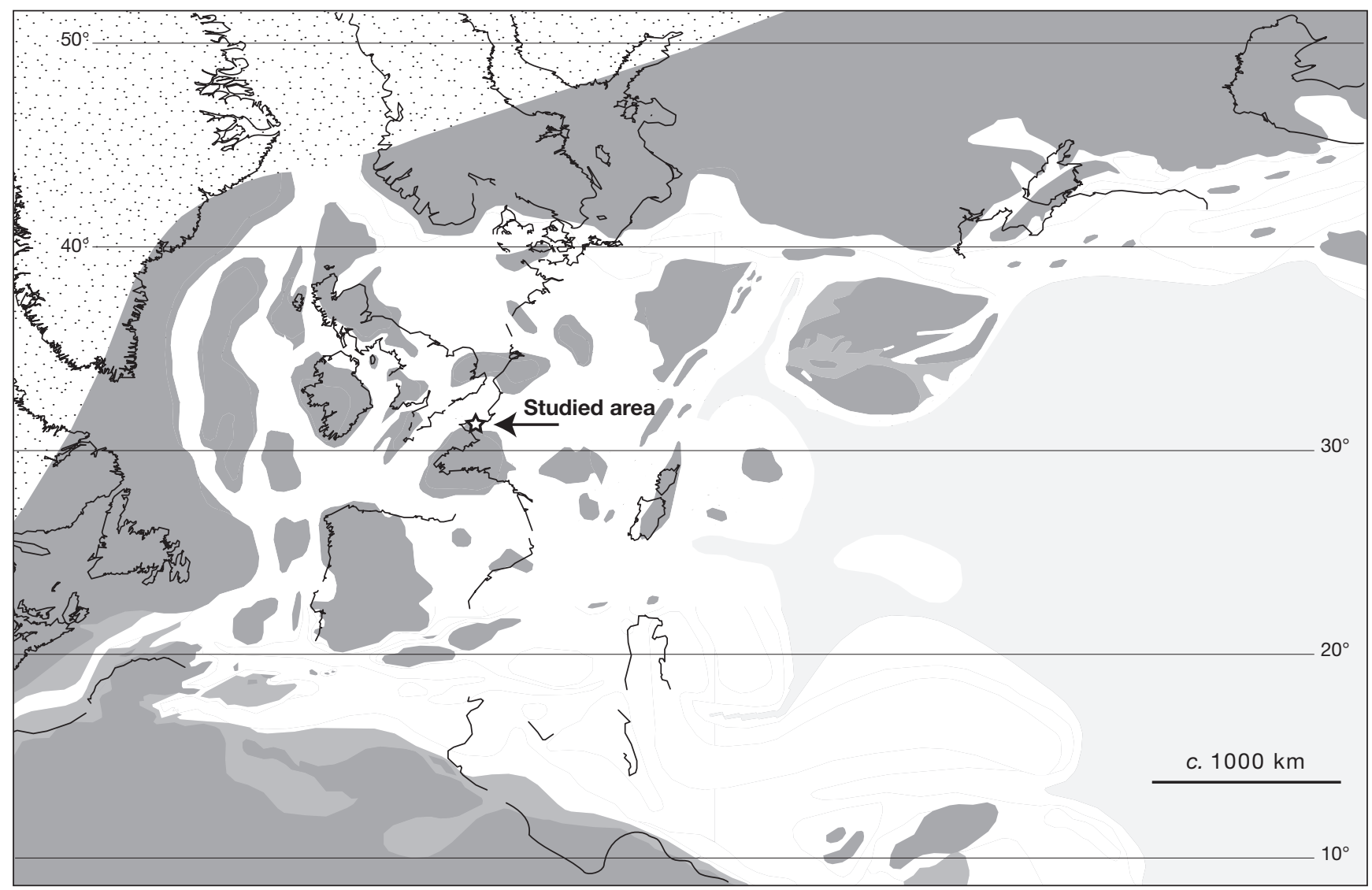

FIG. 2. - Paleogeographical map and location of the Roche Blain quarry during the Toarcian (modified after Thierry \& Barrier 2000). Light grey, deep oceanic basins; white, shallow marine to deep marine; mid-grey, shallow environments with fluctuating salinities; dark grey, exposed land.

adding to their chronostratigraphical scheme for this section (Figs 3, 4). This scheme, as elaborated by Page (2003), corresponds to a standard zonation scheme where chronozones (and subchronozones) are defined by their base only. It gives us the opportunity to establish a framework which will serve as a reference to document the temporal distribution of the belemnite species (Figs 5, 6).

The systematic description of the ammonite faunas exceeds the scope of the present paper, but the section yields taxa wellknown from the north-west European paleobiogeographical province (Howarth 1992; Dommergues et al. 1997; Page 2003). Therefore, we figured only some stratigraphically important species (Figs 7-9).

\section{MATERIAL AND METHODS}

The fossils were collected in 2015 and 2017 during joint field work by collaborators from the Luxembourg Natural History Museum, and the universities of Caen and of Burgundy (Dijon). All the specimens were collected in situ (unless otherwise specified), including numerous ammonites, and some 200 belemnite specimens, of which 164 were identified at species level. The studied belemnite material is housed at the Musée national d'Histoire naturelle de Luxembourg (MNHNL); the illustrated ammonite specimens are housed partially at the geological collections of Université de Bourgogne (UBGD) and in part at the MNHNL. Additional belemnites from the Feuguerolles-sur-Orne section, used herein as a control for belemnite diversity in Normandy (Table 1), are housed in the private collection of Marc Chesnier (Cresserons, Calvados, France).

In general, the preservation of the belemnite rostra is good, although phragmocones are rarely preserved. Most specimens show traces of endo- and/or epibionts. The collected rostra were cleaned from the matrix using a sandblaster with iron powder at 6-8 bar pressure. Illustrated ammonites and belemnites were coated with magnesium oxide prior to photographing.

\section{SYSTEMATIC DESCRIPTIONS}

The systematic employed herein follows the proposals and revisions of Doyle (1994, 2003, 2010), Riegraf et al. (1998), Riegraf (2000), and Weis et al. (2015b). Synonymy lists and geographic occurrences are confined to papers with detailed descriptions and/or proper illustrations, eventual additional synonyms may be found consulting the indicated literature, 


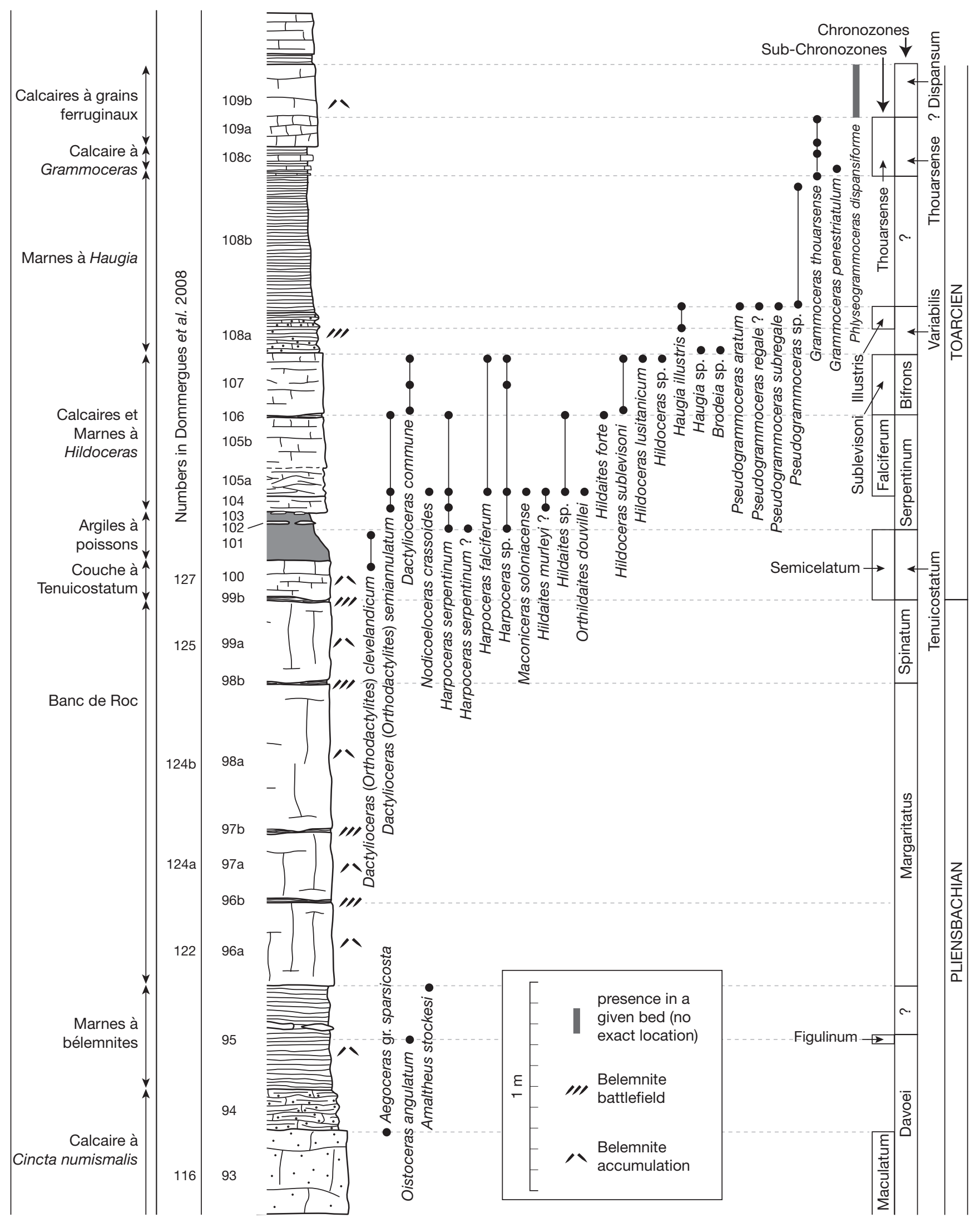

FIG. 3. - Stratigraphic occurence of collected ammonites and chronostratigraphic scheme of the section (Part 1, bottom). Left: main lithostratigraphic units recognised in the literature (Formations or Members, see text), following Dugué et al. 1998. 


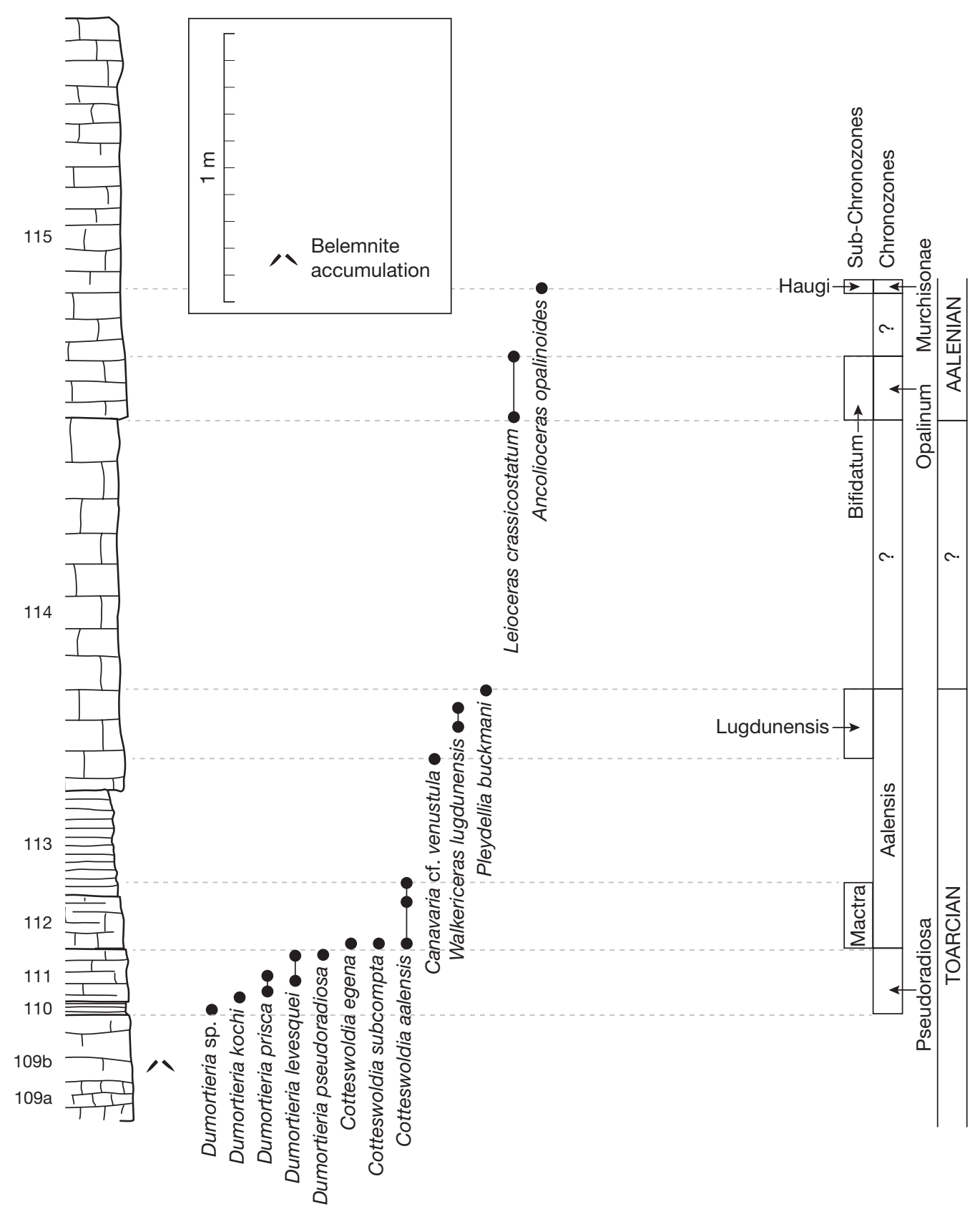

FIG. 4. - Stratigraphic occurence of collected ammonites and chronostratigraphic scheme of the section (Part 2, top).

especially the references marked by "cum syn.". Descriptive terms are used according to Doyle \& Kelly (1988) and Doyle (1990), while size categories are as follows: "very small" (<30 mm), "small" 30-60 mm, "medium" (61-100 mm), "large" (101-150 mm), and "very large" (> $150 \mathrm{~mm})$. The used compression index $\left(I_{c}\right)$ is the ratio between the dorso-ventral diameter and the lateral diameter; values of $>1$ indicate a (laterally) compressed rostrum, values of < 1 indicate a (dorsoventrally) depressed rostrum. Further measurements were not retained useful for the purpose of the present paper, as most taxa are represented by only a few, often fragmentary, specimens.
Order BELEMNITIDA Zittel, 1895

Suborder BELEMNITINA Zittel, 1895

Family HASTITIDAE Naef, 1922

Genus Hastites Mayer-Eymar, 1883

Type SPecies. - Belemnites clavatus Schlotheim, 1820, by subsequent designation (Naef 1922) (= Belemnites neumarktensis Oppel, 1856; subj. syn.) from the uppermost Toarcian (? Opalinuston Fm) of Franconia, south-east Germany (see revision by Riegraf 2000).

DisTRibuTiON. - Upper Toarcian to lowermost Bajocian of Europe and northern Russia. 


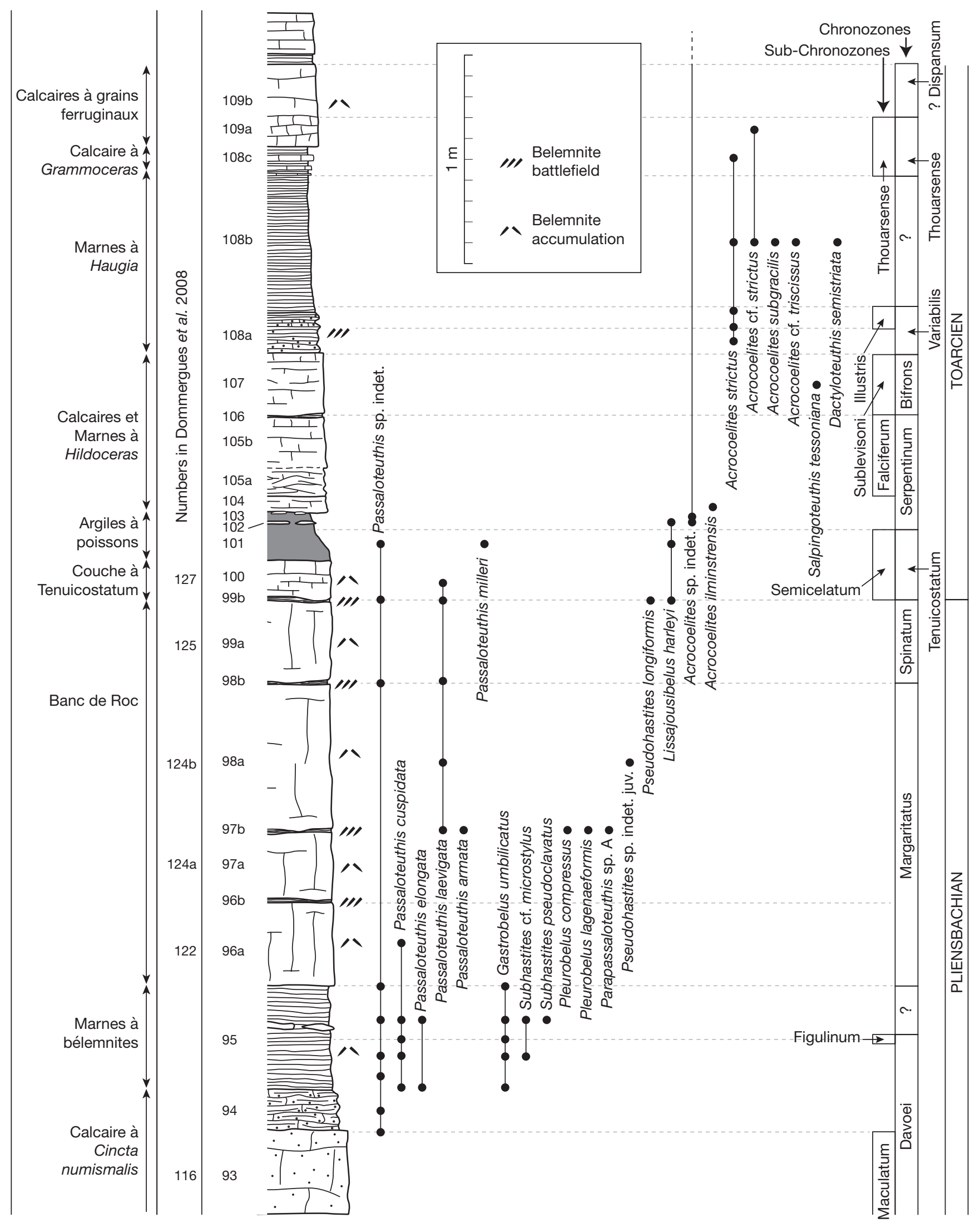

FIG. 5. - Stratigraphic occurence of collected belemnites (Part 1, bottom). Chronostratigraphic and lithostratigraphic scheme following Figure 3. 


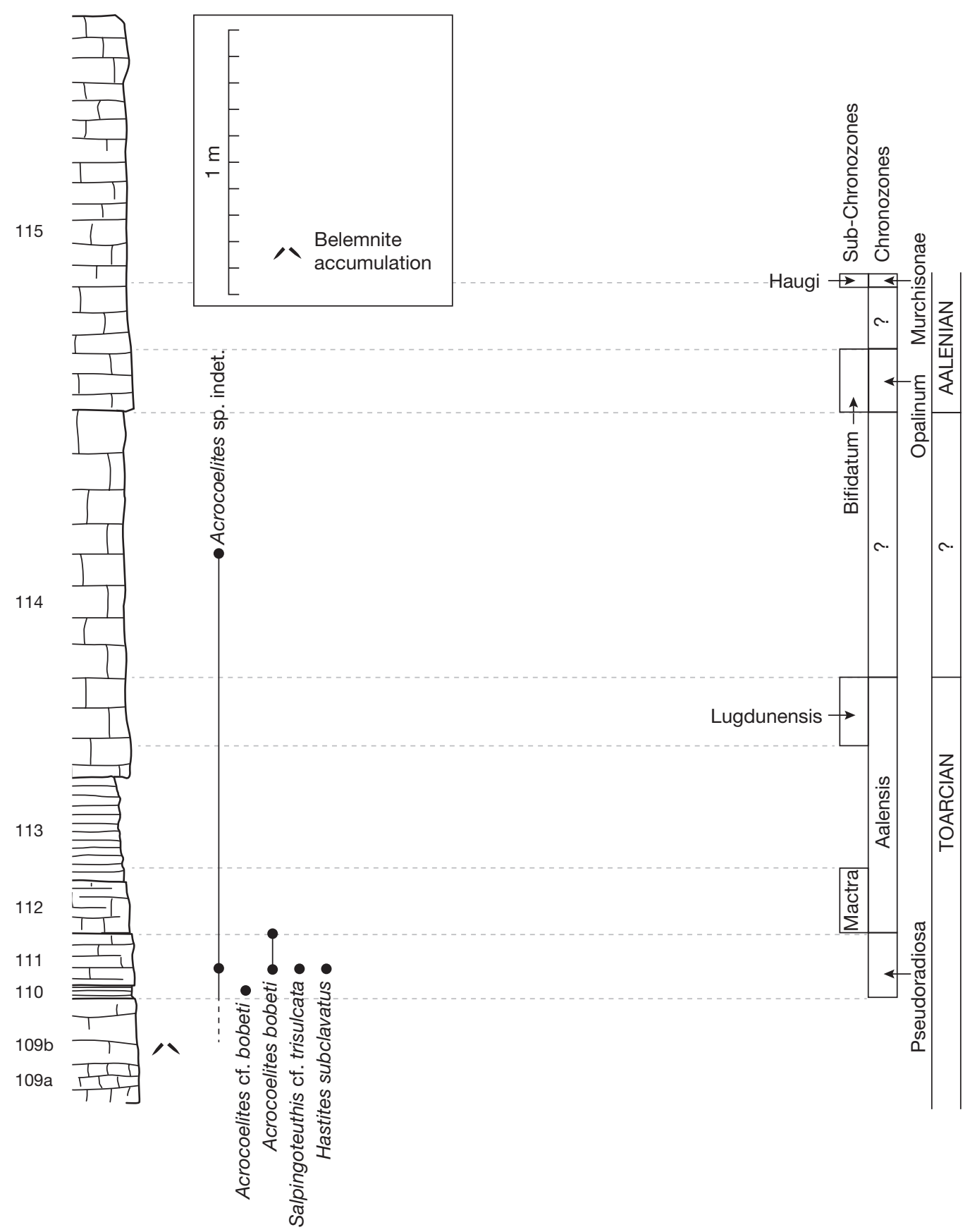

FIG. 6. - Stratigraphic occurence of collected belemnites (Part 1, bottom). Chronostratigraphic scheme following Figure 4.

Hastites subclavatus (Voltz, 1830)

(Fig. 10A)

Belemnites subclavatus Voltz, 1830: 38, pl. 1, fig. 11.

Rhabdobelus subclavatus - Sturz-Köwing 1960: 9, pl. 1, figs 5, 6, 11.

Hastites toarcensis - Činčurová 1975: 49, pl. 1, fig. 4.

Rhopalobelus subclavatus - Činčurová 1983: 10, 55, text-fig. 5; pl. 1, figs 5a,b.

Rhopalobelus toarcensis - Činčurová 1983: 11, 55, text-fig. 6; pl. 1, figs $6 a$, b.
Neoclavibelus subclavatus - Schlegelmilch 1998: 73, pl. 12, figs 4-7.

Parahastites subclavatus - Weis 1999: 226, fig. 22.

Hastites subclavatus - Riegraf 2000: 285.

Neoclavibelus toarcensis - Arp 2010: pl. 4, figs 21-22.

Neoclavibelus bergensis - Arp 2010: pl. 4, figs 23-24.

Material. - One specimen (MNHNL BEL489).

STRATIGRAPHiCAL Distribution. - Upper Toarcian, Pseudoradiosa Chronozone up to Aalensis Chronozone. Fresney-le-Puceux: "Calcaire à grains ferrugineux" Mb, bed 111 . 
GeOGRAPHIC DistribUtion. — North-west Germany (Sturz-Köwing 1960); south Germany, Swabia and Franconia (Kolb 1942; Schwegler 1971; Schlegelmilch 1998; Arp 2010); Slovakia (Činčurová 1975, 1983); north-east France and Luxembourg (Voltz 1830; Weis 1999); north-west France, Normandy (this work).

\section{DESCRIPTION}

This small-sized, slender rostrum shows a slightly subclavate profile and outline. The apical region is short andsharply pointed. Lateral lines are indistinct. Cross sections are elliptical compressed in the stem region, and subquadrate compressed in the alveolar region; $I_{c}=1.08$ (measured at half of the rostrum length). The alveolus occupies approximately $1 / 4$ of the total rostrum length.

\section{REMARKS}

The taxonomic status of the genus Hastites and its type species Hastites clavatus (Schlotheim, 1820) have been revised by Riegraf (2000), confining thereby the genus Hastites to hastate rostra occurring in the upper Toarcian, in opposition to the better known hastate forms of the Pliensbachian, now referred to as Subhastites Gustomesov, 1977, with type species Subhastites pseudoclavatus Gustomesov, 1977 (see below). Statistical analysis by Sturz-Köwing (1960), based on material from the north-west of Germany, and including data from Kolb (1942), demonstrated that the taxa established by Kolb (Hastites forthensis Kolb, 1942; Hastites bergensis Kolb, 1942; Hastites compactus Kolb, 1942) and Oppel (Belemnites toarcensis Oppel, 1857) might be variants of one single, highly variable species. Riegraf (2000: 285) on the other hand considered the possibility to include Hastites forthensis Kolb, 1942 and Hastites bergensis Kolb, 1942 in the specific variation of Hastites clavatus. According to both above mentioned opinions, only two valid species are currently retained: Hastites clavatus, senior subjective synonym of Hastites neumarktensis (Oppel, 1857) and Hastites subclavatus.

\section{Genus Subhastites Gustomesov, 1977}

TyPe SPECIES. - Subhastites pseudoclavatus Gustomesov, 1977 (by original designation) from the Pliensbachian of Côte d'Or, Burgundy, France.

Distribution. - Sinemurian to Pliensbachian of mainland Europe and possibly Greenland.

\section{Subhastites pseudoclavatus Gustomesov, 1977} (Fig. 10C)

Subhastites pseudoclavatus Gustomesov, 1977: 106, pl. 1, fig. 8, pl. 2, fig. 1. - Riegraf et al. 1998: 203. — Weis et al. 2015b: 735, fig. 2c.

Belemnites clavatus Stahl, 1824: 31, pl. 2, fig. 2.

Hastites fustiformis Lang, 1928: 218, pl. 15, fig. 6 (fide Doyle 2010).

Hastites clavatus clavatus - Schumann 1974: 30, pl. 6, figs 1-7.

Hastites clavatus - Schlegelmilch 1998: 57, pl. 4, figs 13-17. Doyle 2010: 273, pl. 47, figs 13, 14.

Hastites clavatus - Combémorel 1997: pl. 27, fig. 4. - Rulleau 2007: 75, pl. 41, fig. 8 .
MATERIAL. — One specimen (MNHNL BEL503).

Stratigraphical Distribution. - Lower Pliensbachian, Ibex and Davoei chronozones. Fresney-le-Puceux: "Marnes à bélemnites" Mb, bed 95 (upper part).

GeOgRaphic Distribution. - North-west Germany (Schumann 1974); south-west Germany (Schwegler 1962; Schlegelmilch 1998); England, Dorset and Yorkshire (Phillips 1865; Lang 1928; Doyle 2003, 2010); north-east France and Luxembourg (R. Weis unpublished field data); north-west France, Normandy (this work); central France, Mont d'Or Lyonnais (Rulleau 2007); south France, Lozère (Combémorel 1997); central Italy (Weis et al. 2015b).

\section{DESCRIPTION}

The very small sized rostrum is strongly hastate ("club-shaped") and shows no grooves or other imprints. The anterior end shows typical exfoliated rostral layers. The alveolar region is not preserved.

\section{REMARKS}

The shape of the rostrum and the exfoliated anterior part are typical for the species Subhastites pseudoclavatus (= Hastites clavatus Auctorum [pars]; see Riegraf 2000).

\section{Subhastites cf. microstylus (Phillips, 1867)} (Fig. 10B)

Belemnites microstylus Phillips, 1867: 66, pl. 13, fig. 31.

cf. Belemnites microstylus - Dumortier 1869, pl. 4, figs 16-19.

cf. Hastites microstylus microstylus - Schumann 1974: 34: pl. 7, figs 11-21; pl. 8, figs 1, 2.

cf. Hastites clavatus - Combémorel et al. 1994: 15, pl. 3, fig. 2.

cf. Hastites microstylus - Schlegelmilch 1998: 57, pl. 5, fig. 1. Rulleau 2007: 42, figs 16-19.

MATERIAL. - Two specimen (MNHNL BEL526a, b).

StratigraPhical Distribution. — Lower Pliensbachian, Jamesoni up to Davoei chronozones. Fresney-le-Puceux: "Marnes à bélemnites" $\mathrm{Mb}$, bed 95 (upper part).

GEOGRAPHIC DisTRIBUTION. — England (Phillips 1867); north-east France (Combémorel et al. 1994); Luxembourg (R. Weis unpublished field data); central France, Mont d'Or Lyonnais (Dumortier 1869; Rulleau 2007); north-west Germany (Schumann 1974); south Germany (Schlegelmilch 1998); Bulgaria (Stoyanova-Vergilova 1993).

\section{DESCRIPTION}

The preserved apical fragments belong to a cylindrical or subhastate, presumably small-sized rostrum. The elongated apical region narrows more or less regularly. Lateral lines are present as two closely-spaced imprints ("Doppellinien"). Cross sections at the broken ends are rounded.

\section{REMARKS}

Only two small-sized apical fragments were recovered from the "Marnes à bélemnites". Their rather cylindrical 


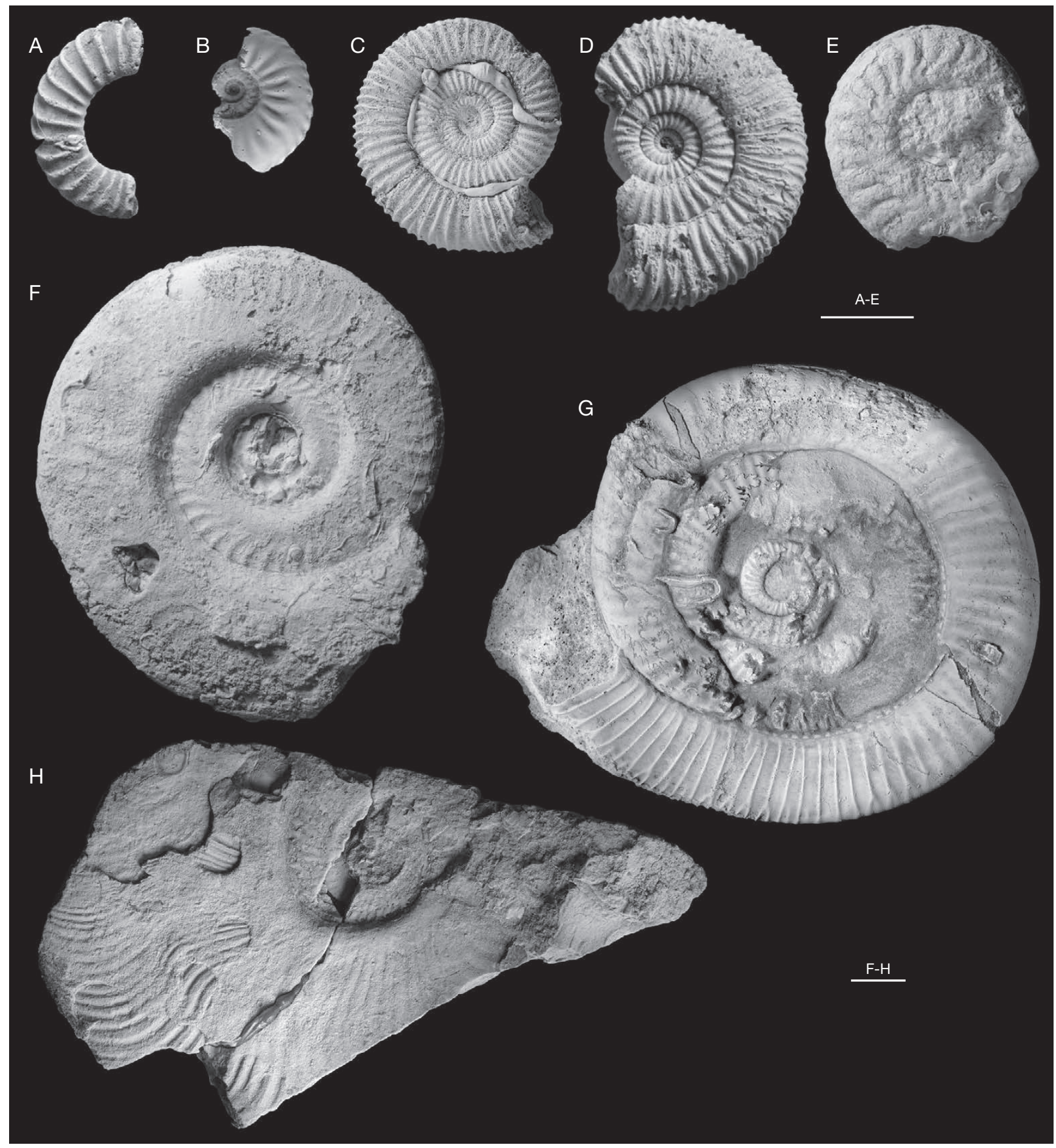

FiG. 7. - Pliensbachian and lower Toarcian ammonites from Fresney-le-Puceux: A, Oistoceras angulatum (Quenstedt, 1858), specimen no. UBGD 30599, "Marnes à bélemnites", bed 95 (middle part); B, Amaltheus stockesi (Sowerby, 1818), specimen no. MNHNL QH644, "Marnes à bélemnites", bed 95 (top); C, D, Dactylioceras (Orthodactylites) annulatum (Sowerby, 1819), "Calcaires et marnes à Hildoceras", bed 105a; C, specimen no. UBGD 30600; D, specimen no. UBGD 30601; E, Hildaites forte (Buckman, 1921), specimen no. UBGD 30602, "Calcaires et marnes à Hildoceras", bed 106; F, Hildoceras lusitanicum Meister, 1913, specimen no. UBGD 30603, "Calcaires et marnes à Hildoceras", bed 107 (top); G, Dactylioceras (Orthodactylites) clevelandicum Howarth, 1973, specimen no. UBGD 30604, "banc de Roc" s.l., bed 100 (top); H, Harpoceras serpentinum (Schlotheim, 1813), specimen no. UBGD 30605, "Argiles à poissons", bed 101 (nodular level). Scale bar: $1 \mathrm{~cm}$.

and elongate apical region allows comparing them with Subhastites microstylus, a thin, needle-like hastitid species. A similar species, Subhastites stonebarroensis (Lang, 1928) has been described from England (Lang 1928; Doyle
2010). This species was first considered as a synonym of Subhastites spadixari (Simpson, 1855) by Doyle (2003); later, the same author (Doyle 2010) reported it as a synonym of $S$. microstylus. 


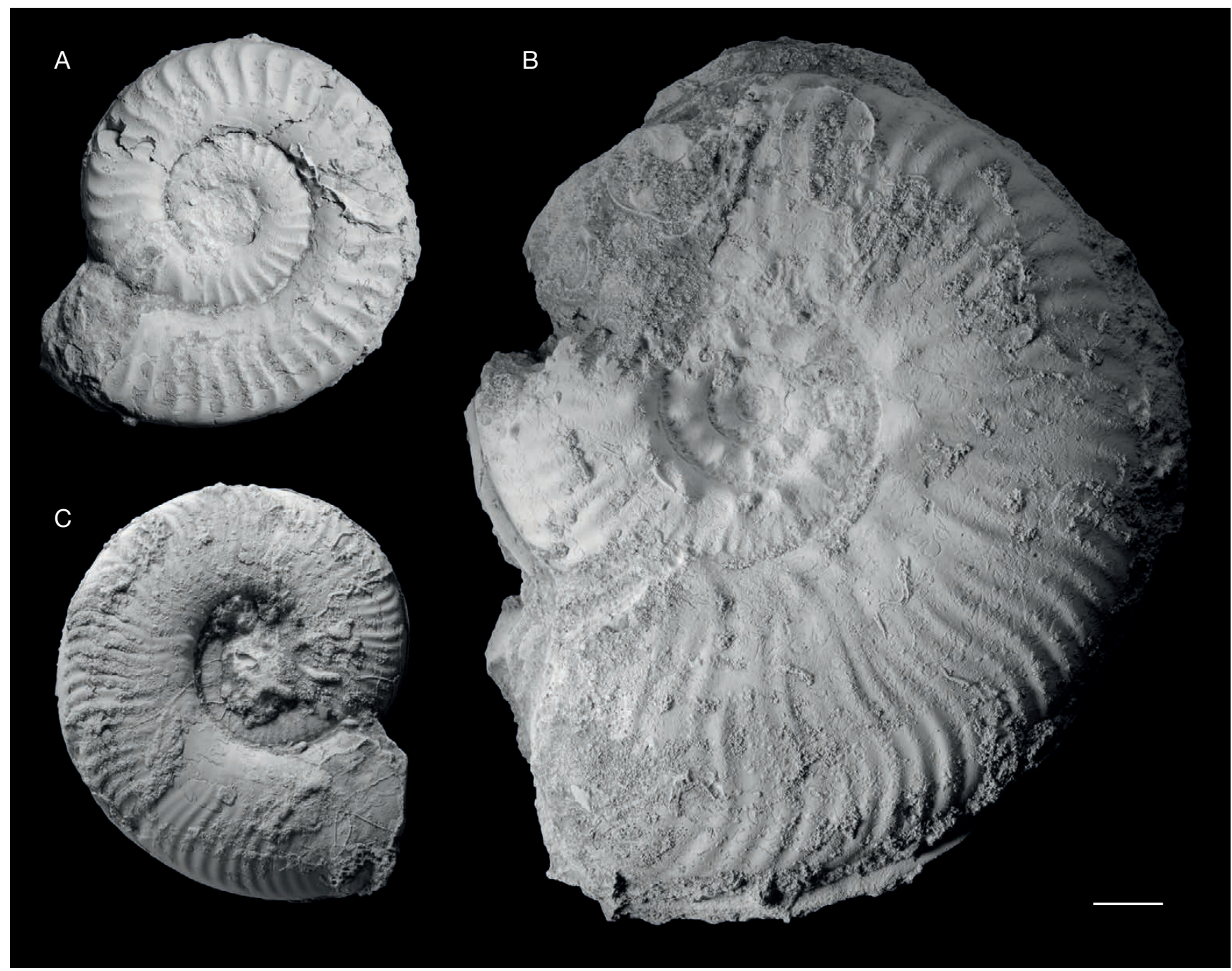

FIG. 8. - Upper Toarcian ammonites (part 1) from Fresney-le-Puceux: A, Grammoceras penestriatulum (Schirardin, 1914), specimen no. UBGD 30606, "Calcaire à Grammoceras", bed 108c; B, Haugia illustris (Denckmann, 1887), specimen no. UBGD 30607, "Marnes à Haugia”, bed 108a; C, Pseudogrammoceras subregale Pinna, 1968, specimen no. UBGD 30608, "Marnes à Haugia”, bed 108b (base). Scale bar: $1 \mathrm{~cm}$.

Family MEgateuthididAE Sachs \& Nalnjaeva, 1967

Genus Acrocoelites Lissajous, 1915

TYPE SPECIES. - Belemnites oxyconus Hehl in Zieten, 1831 (by original designation) from the lower Toarcian, Posidonienschiefer Fm of South-West Germany.

Distribution. - Uppermost Pliensbachian to lower Aalenian of Europe, Siberia, and probably North and South America and Japan.

Acrocoelites bobeti Lissajous, 1927

(Fig. 10D-F)

Acrocoelites bobeti Lissajous, 1927: 19. — Combémorel 1971: 63 , pl. 1, figs 1, 2; 1997: pl. 27, fig. 16. - Doyle 1990: 33, pl. 7, figs 9-11, 13-15. — Pinard et al. 2014: 165, fig. 6C.

MATERIAL. - Six specimens (MNHNL BEL486a, b; BEL487a, b; BEL488; BEL529).
STRATIGRAPHICAL Distribution. - Upper Toarcian, Pseudoradiosa and Aalensis chronozones. Fresney-le-Puceux: "Calcaire à grains ferrugineux" Mb, beds 110 and 111 .

Geographic distribution. — England, Dorset (Doyle 1990); north-west France, Normandy (this work); south France, Aveyron and Lozère (Lissajous 1927; Combémorel 1971, 1997; Pinard et al. 2014).

\section{DESCRIPTION}

The small to medium-sized, slender rostra show a cylindriconical profile and a cylindrical to subhastate outline. The acute apex is relatively short in most specimens and bears a short, well-incised ventral groove and two less developed dorsolateral grooves. Lateral lines are indistinct. The cross section is elliptical compressed, compression is not very marked in the stem region ( $\mathrm{I}_{\mathrm{c}}$ varying between 1.04 and 1.09), but the alveolar region is strongly compressed $\left(\mathrm{I}_{\mathrm{c}}\right.$ between 1.16 and 1.25 ). The alveolus occupies approximately $1 / 3$ to $1 / 6$ of the rostrum. 


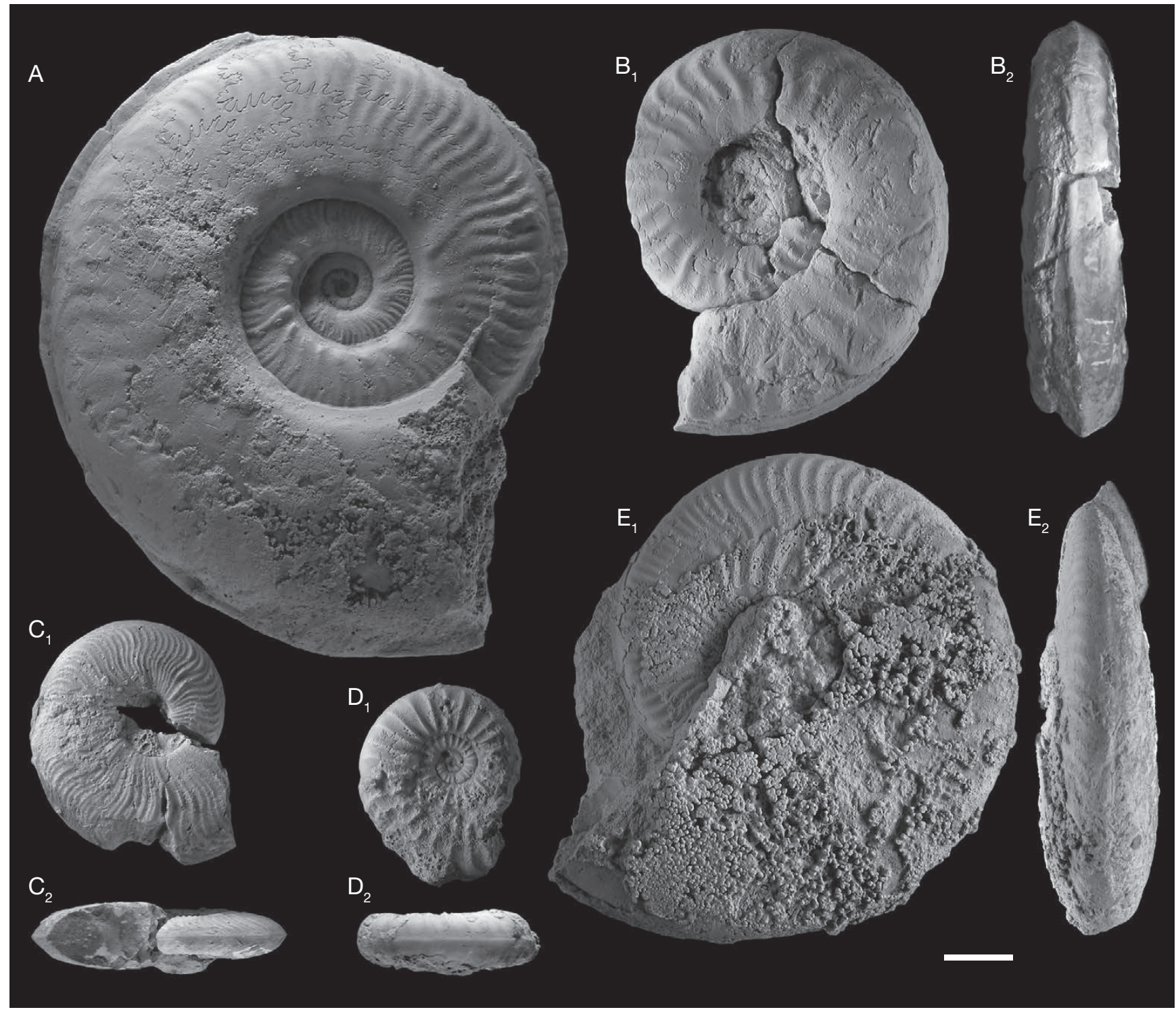

FIG. 9. - Upper Toarcian ammonites (part 2) and Aalenian ammonites from Fresney-le-Puceux: A, Phlyseogrammoceras dispansiforme (Wunstorf, 1904), specimen no. MNHNL QH622, "Calcaire à grains ferrugineux", bed 109b; B, Grammoceras thouarsense (d'Orbigny, 1843), specimen no. MNHNL QH627, "Calcaire à Grammoceras”, bed 108c; C, Pleydellia buckmani (Maubeuge, 1947), specimen no. MNHNL QH628, bed 114; D, Dumortieria prisca Buckman, 1891, specimen no. MNHNL QH632, "Calcaire à grains ferrugineux", bed 111; E, Ancolioceras opalinoides (Mayer, 1864), specimen MNHNL QH625, bed 115. Scale bar: $1 \mathrm{~cm}$.

\section{REMARKS}

The rostra herein referred to $A$. bobeti are morphologically comparable to the stratigraphically older Acrocoelites strictus Lissajous, 1927 (see also below for morphological differences). Some individuals with a more pronounced subhastate outline (Fig. 10D) approach the genus Simpsonibelus, but lack the subquadrate cross section, the strongly asymmetrical profile and the pronounced double lateral lines of the latter (Doyle 1992).

\section{Acrocoelites ilminstrensis (Phillips, 1867)} (Fig. 10G)

Belemnites ilminstrensis Phillips, 1867: 64, pl. 12, fig. 30.
Acrocoelites ilminstrensis - Riegraf et al. 1984: 155, pl. 10, figs 2, 3, 5, 9 (cum syn.). — Schlegelmilch 1998: 59, pl. 5, figs 11, 12. Pinard et al. 2014: 165, fig. 6C.

Acrocoelites (Toarcibelus) ilminsterensis [sic] - Doyle 1990: 39, pl. 1, figs 1-7 (cum syn.).

MATERIAL. — One specimen (MNHNL BEL492).

STRATigRAPHICAL Distribution. — Lower Toarcian, Serpentinum and Bifrons chronozones. Fresney-le-Puceux: "Calcaires et Marnes à Hildoceras” Mb, bed 104 .

Geographic distribution. - England, Dorset and Yorkshire (Phillips 1867; Doyle 1990); south Germany (Riegraf et al. 1984; Schlegelmilch 1998); north-west France (this work); central France, Mâconnais, Monts Lyonnais (Lissajous 1906); Luxembourg (R. Weis unpublished field data); Bulgaria (Stoyanova-Vergilova 1993). 


\section{DESCRIPTION}

The medium-sized rostrum is reasonably robust and shows a conical profile and a cylindriconical outline. The acute apex bears two short and weakly preserved dorsolateral grooves; a broader and longer ventral groove is stronger developed. The flanks of the rostrum are flattened, due to the presence of broad, indistinct lateral lines. Cross sections are elliptical, moderately compressed $\left(I_{c}=1.03\right.$, measured at half of the rostrum length). The alveolus occupies approximately $1 / 3$ of the rostrum.

\section{Acrocoelites strictus Lissajous, 1927} (Fig. 10I-L)

Acrocoelites strictus Lissajous, 1927: 16, pl. 2, figs 2-4.

Acrocoelites (Acrocoelites) strictus - Doyle 1990: 32, pl. 7, figs 7, 8, 12.

MATERIAL. - 63 specimens (MNHNL BEL479a-c, BEL480a-s, BEL482a-s, BEL525a-e, BEL528, BEL531a-c, BEL532a-b, BEL533a-d, BEL537a-g).

StratigRAPHICAL DistribUTION. - Toarcian, Bifrons up to Thouarsense chronozones. Fresney-le-Puceux: "Marnes à Haugia" and “Calcaires à Grammoceras" Mb, beds 108a, b, c, and 109.

GeOgRAPHiC Distribution. - England, Northhamptonshire (Lissajous 1927; Doyle 1990); north-west France, Normandy (this work).

\section{DESCRIPTION}

The small to medium sized rostra are moderately robust and show a conical profile and a cylindriconical to slightly subhastate outline. The elongated apical region is tapering regularly towards the acute apex, bearing two well-incised but short dorsolateral grooves and a considerably longer ventral groove; the latter fades out anteriorly resulting in a flattened ventral area: as a result, the apical region is characterized by a slightly depressed cross section. Cross sections in the stem region are rounded or subquadrate, in the alveolar region they become slightly compressed. Lateral lines are indistinctly developed as two parallel running shallow depressions. The alveolus occupies approximately $1 / 3$ to $1 / 4$ of the rostrum length.

\section{REMARKS}

The species resemble the stratigraphically younger Acrocoelites bobeti (see above) and morphologically connecting forms exist in the Dispansum chronozone. Typical specimens of $A$. strictus are characterized by the relatively robust rostrum with a conical profile, the long and broad ventral apical groove and the depressed cross sections of the apical region; these features distinguish them from typical $A$. bobeti, characterized by a more slender rostrum, with cylindrical profile and a short ventral apical groove.

\section{Acrocoelites subgracilis Kolb, 1942} (Fig. 10H)

Acrocoelites subgracilis Kolb, 1942: 161, pl. 8, figs 5-7.

Belemnites tripartitus gracilis Quenstedt, 1848: 420, pl. 26, fig. 17a-c.
Acrocoelites (Acrocoelites) subgracilis - Doyle 1990: 35, pl. 7, fig. 16, pl. 8, figs 1-2 (pars, see remark below). - Schlegelmilch 1998: 60, pl. 6, figs 1-2. - Arp 2010: pl. 4, figs 9-10.

Material. - One specimen (MNHNL BEL485).

STRATIGRAPHical Distribution. - Upper Toarcian, Variabilis or Thouarsense Chronozone up to Aalensis Chronozone. Fresney-lePuceux: "Marnes à Haugia" Member, bed 108b.

Geographic Distribution. - South Germany, Swabia and Franconia (Quenstedt 1845-1849; Kolb 1942; Schlegelmilch 1998); England, Yorkshire, Northamptonshire (Doyle 1990); north-west France, Normandy (this work).

\section{DESCRIPTION}

The estimated medium- to large-sized, slender-elongate rostrum shows a cylindriconical profile and a cylindrical to subhastate outline. A part of the apex is missing, but two weak dorsolateral grooves can be recognized by observing the growth lines in cross section at the broken-off apical end; a long ventral groove extends approximately up to half the length of the rostrum solidum. Lateral lines are developed as broad and shallow lateral depressions, especially well-developed on the alveolar region. Cross sections of the rostrum are elliptical compressed, the compression index $\left(I_{c}\right)$ is varying between 1.08 in the stem region and 1.24 in the alveolar region. The alveolus occupies about $1 / 3$ to $1 / 4$ of the total rostrum.

\section{REMARKS}

The species is here interpreted in the sense of Kolb (1942) and Schlegelmilch (1998), who limit it to the rostra from the upper Toarcian. The species concept proposed by Doyle (1990) is a broader one, as he includes also stratigraphically older material from the Bifrons/Variabilis chronozones. The latter are currently referred to other species such as Salpingoteuthis persulcata (Janensch, 1902) (in Riegraf et al. 1984: 163, pl. 12, fig. 11; referred to Salpingoteuthis bauhini [nomen novum established by Schlegelmilch 1998]). In our opinion the latter taxa should be maintained distinct, although their generic attribution remains debatable.

\section{Acrocoelites cf. triscissus (Janensch, 1902)}

(Fig. 11A)

cf. Belemnites triscissus - Janensch 1902: 8, pl. 12, figs 7-7b.

cf. Acrocoelites triscissus - Kolb 1942: 157, pl. 9, figs 3, 6.

cf. Acrocoelites (Odontobelus) triscissus - Doyle 1990: 46, pl. 16, figs 1-5. - Rulleau et al. 1998 : 19, pl. 1, figs 1-2.

Material. - One specimen (MNHNL BEL483).

Stratigraphical Distribution. - Upper Toarcian, Variabilis up to Aalensis chronozones. Fresney-le-Puceux: "Marnes à Haugia" $\mathrm{Mb}$, bed 108b.

GeOgRAPHiC DisTribution. — England, Yorkshire, Gloucestershire (Doyle 1990); north-east France, Alsace (Janensch 1902); Luxembourg (R. Weis unpublished field data); north-west France, Normandy (this work); south Germany, Franconia (Kolb 1942). 


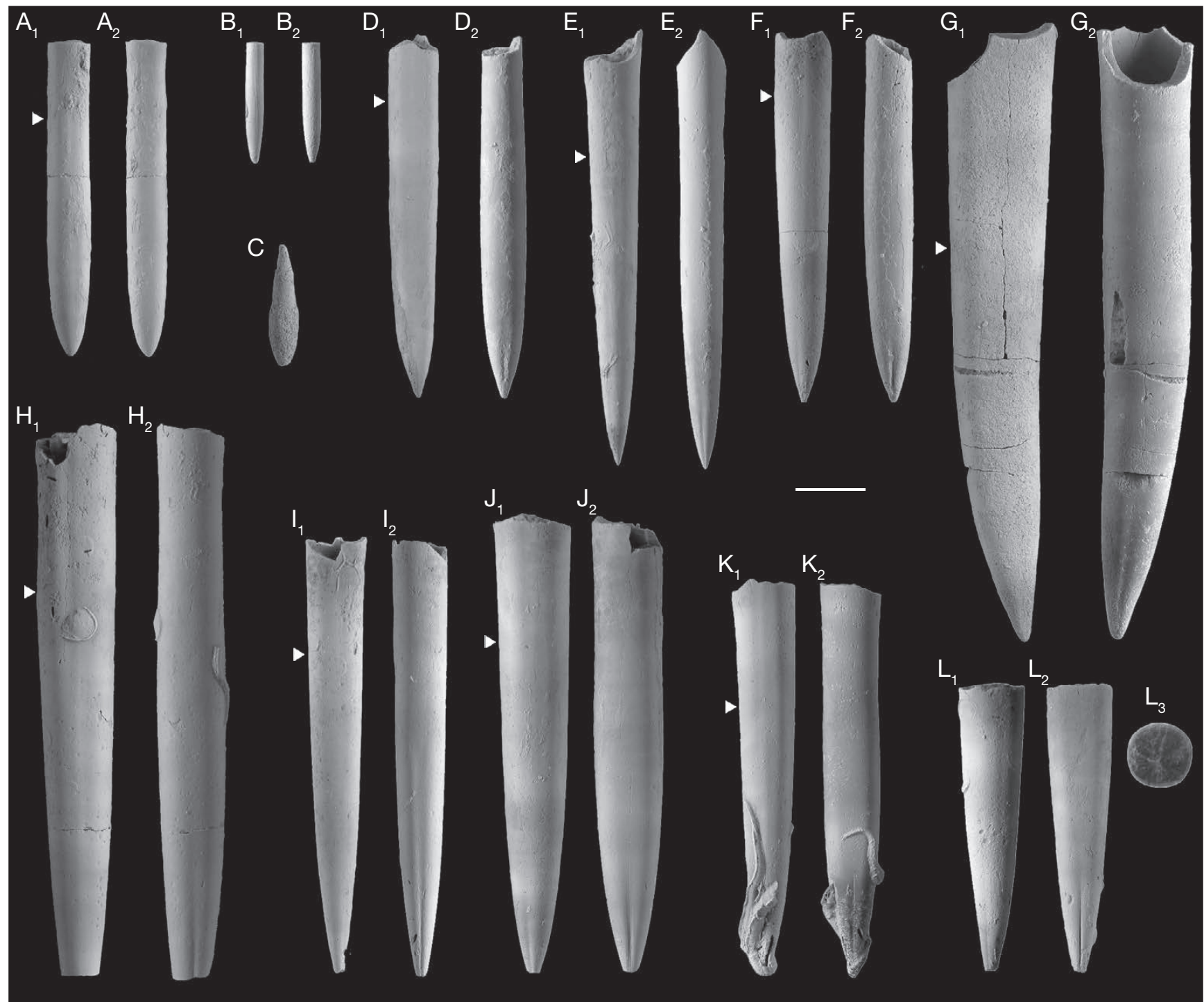

FIG. 10. - Hastitidae and Megateuthididae (part 1), Pliensbachian-Toarcian of Fresney-le-Puceux: A, Hastites subclavatus (Voltz, 1830), specimen no. MNHNL BEL489, bed 111; A1, lateral view; A2, ventral or dorsal view; B, Subhastites cf. microstylus (Phillips, 1867), apical fragment, specimen no. MNHNL BEL526a, bed 95; B1, lateral view; B2, ventral or dorsal view; C, Subhastites pseudoclavatus Gustomesov, 1977, corroded specimen without alveolar part, no. MNHNL BEL503, bed 95, non-orientated view; D-F, Acrocoelites bobeti Lissajous, 1927; D, specimen no. MNHNL BEL487b, bed 111 (top); D1, lateral view, venter right; D2, ventral view; E, specimen no. MNHNL BEL487a, bed 111 (top); E1, lateral view, venter right; E2, ventral view; F, specimen no. MNHNL BEL486a, bed 110; F1, lateral view, venter right; F2, ventral view; G, Acrocoelites ilminstrensis (Phillips, 1867), specimen no. MNHNL BEL492, bed 104; G1, lateral view, venter left; G2, ventral view; H, Acrocoelites subgracilis Kolb, 1942, apex not preserved, no. MNHNL BEL485, bed 108; H1, lateral view, venter right; H2, ventral view; I-L, Acrocoelites strictus Lissajous, 1927; I, specimen no. MNHNL BEL480a, bed 108 (top); I1, lateral view, venter left; I2, ventral view; J, specimen no. MNHNL BEL482a, bed 108; J1, lateral view, venter right; J2, ventral view; K, specimen with serpulid incrustations, no. MNHNL BEL482b, bed 108; K1, lateral view, venter left; K2, ventral view; L, apical fragment of a large specimen, no. MNHNL BEL480b, bed 108 (top); L1, lateral view, venter right; L2, ventral view, L3, cross section. Scale bar: $1 \mathrm{~cm}$. White arrows indicate the estimated position of the protoconch.

\section{DESCRIPTION}

The specimen represents a robust, conical to cylindriconical rostrum with the apical and stem region preserved, but missing the alveolar region completely. The conical apical region shows three equally long and well-developed apical grooves; the dorsolateral grooves are slightly curved towards the dorsum. The ventral groove is slightly deeper and broader than the dorsolateral ones. The cross sections are elliptical and slightly compressed $\left(\mathrm{I}_{\mathrm{c}}=1.04\right.$ at protoconch level).

\section{REMARKS}

Despite its incomplete state of preservation, the specimen shows typical characters of the apical region (e.g. the strongly developed apical grooves, with curved dorsolateral grooves) which permit to compare it to $A$. triscissus. This species is included by most authors within the variation range of either $A$. quenstedti (Oppel, 1856) (Werner 1912) or $A$. conoideus (Oppel, 1856) (Schlegelmilch 1998). Based on a statistical approach, Sturz (1958) synonymized $A$. triscissus with both $A$. conoideus and $A$. quenstedti, giving 
priority to the latter name. On the other hand, Doyle (1990) considered these three taxa as independent species. In lack of a comprehensive review of Acrocoelites and a better understanding of the intraspecific variability, for the time being we consider here $A$. triscissus herein as a distinct taxon.

\section{Genus Dactyloteuthis Bayle, 1878}

TYPe SPECIES. - Belemnites irregularis Schlotheim, 1813 (by subsequent designation of Douvillé 1879), from the upper Toarcian, Jurensismergel Fm of Franconia, South-East Germany.

Distribution. - Upper Toarcian of West and Central-East Europe.

\section{Dactyloteuthis semistriata (Münster, 1830)}

(Fig. 11B)

Belemnites semistriatus Münster, 1830: 15, pl. 2, fig. 4.

Belemnites (Dactyloteuthis) acuarius - Lissajous 1906: 55, pl. 4, fig. 8.

Dactyloteuthis semistriata - Riegraf et al. 1984: 163, pl. 12, figs 4, 12, text-fig. 48u. — Schlegelmilch 1998: 66, pl. 9, figs 8-10. Delsate \& Weis 2010: pl. 5, fig. 2.

Dactyloteuthis irregularis - Combémorel et al. 1994: pl. 1, figs 4-5 (non figs 1-3).

\section{MATERIAL. — One specimen (MNHNL BEL484).}

StRATIGRAPHICAL DisTRIBUTION. - Upper Toarcian, Variabilis chronozone and Thouarsense chronozone. Fresney-le-Puceux: "Marnes $\grave{a}$ Haugia" Mb, bed 108b.

GeOgRaPhic Distribution. — North-west Germany (Sturz-Köwing 1960); south Germany, Swabia and Bavaria (Riegraf et al. 1984; Schlegelmilch 1998); north-west France, Normandy (this work); central France, Mâconnais (Lissajous 1906); north-east France, Lorraine (Combémorel et al. 1994); Luxembourg (Delsate \& Weis 2010). Probably also south France, Causses (Pinard et al. 2014, recorded as $D$. cf. semistriata).

\section{DESCRIPTION}

The small sized, stout orthorostrum (the epirostrum is not preserved) shows a cylindriconical outline and profile. The obtuse apex is mucronate and bears several fine apical striae; a shallow and weakly developed ventral apical groove is present. Cross sections are elliptical compressed $\left(I_{c}=1.21\right.$ at half of the rostrum length). The alveolus occupies approximately $2 / 3$ of the rostrum.

\section{Family Passaloteuthididae Naef, 1922}

\section{Genus Gastrobelus Naef, 1922}

TYPE SPECIES. - Belemnites ventroplanus Voltz, 1830 (by original designation), from the Pliensbachian of Alsace, north-east France.

Distribution. - Pliensbachian to lowermost Toarcian of Europe and Greenland.
Gastrobelus umbilicatus (Blainville, 1827)

(Fig. 11C-G)

Belemnites umbilicatus Blainville, 1827: 97, pl. 3, fig. 11.

Hastites umbilicatus - Combémorel et al. 1994: 10, pl. 1, fig. 6.

Gastrobelus umbilicatus - Schlegelmilch 1998: 53, pl. 3, fig. 8. Rulleau 2007: pl. 41 fig. 12.

Gastrobelus ventroplanus - Doyle 2010: 274, pl. 47, figs 3-4.

MATERIAL. - 36 specimen (MNHNL BEL506, BEL507, BEL508, BEL510, BEL511, BEL517a-j, BEL518a-c, BEL519a-k, BEL535a-b, BEL539a-e).

STRATigraphiCAL Distribution. - Pliensbachian, Davoei up to Margaritatus Chronozone. Fresney-le-Puceux: "Marnes à Belemnites" $\mathrm{Mb}$, bed 95.

GeOgraphiC Distribution. - North-west France, Normandy (this work); central France, Mont d'Or Lyonnais (Combémorel et al. 1994; Rulleau 2007); south Germany (Schlegelmilch 1998); England, Dorset (Doyle 2010: reported as G. ventroplanus).

\section{DESCRIPTION}

The medium sized, slender-elongate rostra show a cylindrical to subhastate profile and a subhastate outline. The apical region is elongated to short (at later ontogenetic stages), and obtuse; several short and weak apical striae are present in some individuals. Lateral lines are usually well developed, especially in the alveolar region. Cross sections in the apical and stem regions are subtriangular depressed, due to a marked ventral flattening which extends over the whole rostrum solidum. In the alveolar region, cross sections are less depressed and rather subquadrate. The alveolus occupies about $1 / 5$ to $1 / 6$ of the rostrum length.

\section{REMARKS}

Larger specimens, such as the specimen illustrated in Figure $11 \mathrm{G}$, develop an obtuse apex and a more robust rostrum, reminding elongated specimens of $G$. ventroplanus. Combémorel et al. (1994: 11) and Lissajous (1925: 151) considered $G$. umbilicatus as a senior subjective synonym of $G$. ventroplanus, a species which is short and stout, with a strongly marked ventral depression. Schwegler (1965), Schumann (1974) and Schlegelmilch (1998) kept these taxa separated, but mentioned the presence of numerous morphological transitional forms between them. In absence of a comprehensive review of the genus, the distinction of the two taxa is here maintained.

\section{Genus Parapassaloteuthis Riegraf, 1980}

TYPe sPeCIEs. - Belemnites zieteni Werner, 1912 (by original designation), from the upper Pliensbachian, Amaltheenton Fm of south-west Germany.

Distribution. - Pliensbachian to lower Toarcian of Europe, northern Africa and Greenland. 


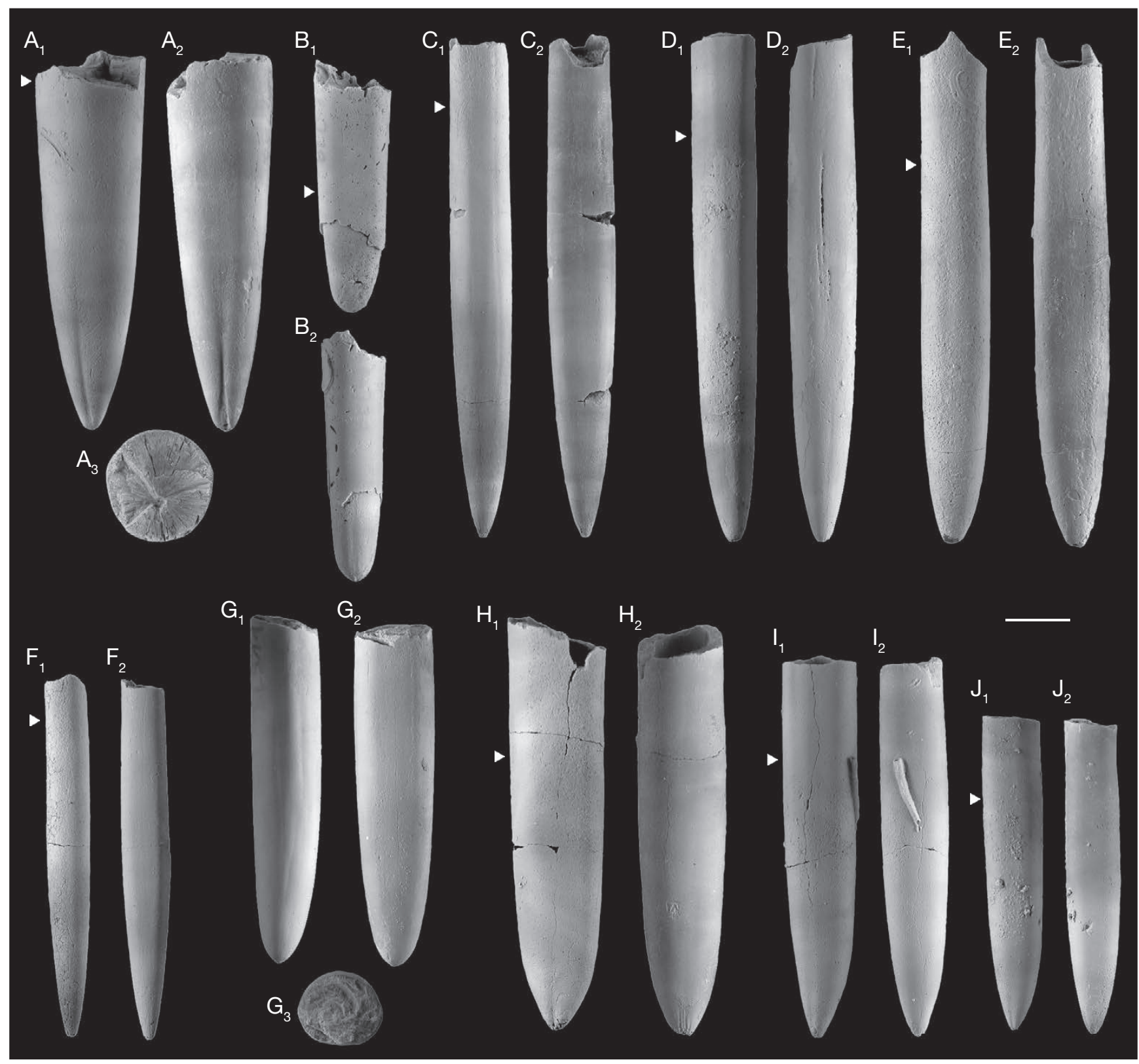

FiG. 11. - Megateuthididae (part 2) and Passaloteuthididae (part 1), Pliensbachian-Toarcian of Fresney-le-Puceux: A, Acrocoelites cf. triscissus (Janensch, 1902), alveolar region not preserved, specimen no. MNHNL BEL483, bed 108; A1, lateral view, venter left; A2, ventral view; A3, cross section, ventral side at bottom; B, Dactyloteuthis semistriata (Münster, 1830), orthorostrum (epirostrum not preserved), specimen no. MNHNL 484, bed 108; B1, lateral view, venter left; B2, ventral view; C-G, Gastrobelus umbilicatus (Blainville, 1827); C, specimen no. MNHNL BEL508, bed 95; C1, lateral view, venter right; C2, ventral view; D, specimen with a scar (predator attack?) on the ventral side, no. MNHNL BEL509, bed 95 (base); D1, lateral view, venter left; D2, ventral view; E, specimen no. MNHNL BEL507, bed 95; E1, lateral view, venter right; E2, ventral view; F, juvenile/subadult specimen, no. MNHNL BEL506, bed 95; F1, lateral view, venter right; F2, ventral view; G, fragment of a larger specimen, lacking part of the stem and the alveolar region, no. MNHNL BEL511, bed 95; G1, lateral view, venter right; G2, ventral view; G3, cross section of the stem region; H-J, Passaloteuthis armata (Dumortier, 1869); H, specimen no. MNHNL BEL513a, bed 97b; H1, lateral view, venter right; H2, ventral view, showing the apical striae; I, specimen with serpulid incrustation, no. MNHNL BEL513b, bed 97b; I1, lateral view, venter right; I2, ventral view; J, probably juvenile specimen, no. MNHNL BEL513c, bed 97b; J1, lateral view, venter right; J2, ventral view. Scale bar: $1 \mathrm{~cm}$. White arrows indicate the estimated position of the protoconch.

\section{Parapassaloteuthis sp. A}

(Fig. 12H)

?Parapassaloteuthis sp. A - Sanders et al. 2015: 57, figs 8a-i.

MATERIAL. — One specimen (MNHNL BEL501).

Stratigraphical Distribution. — Upper Pliensbachian, Margaritatus Chronozone and possibly lowermost Toarcian, Tenuicostatum Chronozone. Fresney-le-Puceux: "banc de Roc" Mb, bed 97b.
GeOgRAPHiC Distribution. — North-west France, Normandy (this work); possibly also Rif area, Morocco (Sanders et al. 2015).

\section{DESCRIPTION}

Medium sized, robust rostrum, with a cylindrical profile and outline. The obtuse apex bears no grooves. Lateral lines are weakly developed as shallow, broad depressions in the alveolar region. Cross sections are elliptical, compressed; 
the alveolus is ventrally displaced, and occupies $1 / 2$ of the total rostrum length; the apical line is goniolineate. Alveolar angle $c .24^{\circ}$.

\section{REMARKS}

This single rostrum can be tentatively compared with the rostra recorded by Sanders et al. (2015) from the lowermost Toarcian of northern Morocco and described therein as Parapassaloteuthis sp. A.

\section{Genus Passaloteuthis Lissajous, 1915}

Type sPeCIES. - Belemnites bruguierianus d'Orbigny, 1843 (by original designation) $(=$ P. laevigata (Zieten, 1831), senior subjective synonym), from the upper Pliensbachian of Calvados, France (neotype designated in Combémorel et al. 1994).

Distribution. - Pliensbachian to lower Toarcian of Europe, northern Africa, Turkey and Greenland.

\section{REMARK}

Numerous species have been assigned to the genus Passaloteuthis, most of them described by earlier workers in the 19th century and the first half of the $20^{\text {th }}$ century. Some of them have been reviewed by Schumann (1974), Schlegelmilch (1998) and Doyle (1990, 2010). Doyle (2003) revised and illustrated for the first time the nominal species described by Martin Simpson (1855, 1884), reinstating them. Other species include the ones by Lissajous (1927) mainly from central France, Činčurová (1974, 1989, 1991), from Slovakia and Sachs \& Nalnjaeva (1970) from northern Russia, but these species have not been recently reviewed and may represent, at least in part, subjective synonyms, of the taxa recognized as valid by the aforementioned workers.

\section{Passaloteuthis armata (Dumortier, 1869)} (Fig. 11H-J)

Belemnites armatus Dumortier, 1869: 40, pl. 1 figs 13-16.

Belemnites armatus armatus - Schumann 1974: 26, pl. 4, figs 1, 2, 7, 8.

Passaloteuthis armata - Rulleau 2007: pl. 41 fig. 9.

MATERIAL. - Three specimen (MNHNL BEL513a-c).

Stratigraphical Distribution. - Pliensbachian, Jamesoni up to Margaritatus chronozones. Fresney-le-Puceux: "banc de Roc" Mb (lower part), bed 97b.

Geographic distribution. - Central France, Rhône valley, Mont d'Or Lyonnais (Dumortier 1869; Rulleau 2007); north-west France, Normandy (this work); north Germany (Schumann 1974); Bulgaria (Stoyanova-Vergilova 1993); possibly also England, Dorset (see remark below).

\section{DESCRIPTION}

Medium sized, stout rostra with a cylindrical profile and a cylindrical to subhastate outline. The short, acute apex is slightly displaced towards the dorsal side, creating an asymmetrical profile; the apex bears tow short dorsolateral grooves, one specimen shows irregular apical striae on the ventral side only. Lateral lines are well-developed as double, shallow depressions, running parallel on the flanks in a dorsolateral position (in continuation of the dorsolateral apical groove) respectively in a dorsoventral position; the latter depression is more widely and deeply expressed. Cross sections are subquadrate, compressed $\left(\mathrm{I}_{\mathrm{c}}\right.$ ranging between 1.04 and 1.09; measurements taken at half of the total rostrum length); in the alveolar region, the ventral part of the section is rounded, meanwhile the dorsal part is flattened. The alveolus occupies approximately $1 / 3$ of the total rostrum length.

\section{REMARKS}

The species Passaloteuthis ridgensis Lang, 1928 from the lower Pliensbachian (Jamesoni-Ibex chronozones) of Dorset strongly resembles Passaloteuthis armata and might be a junior subjective synonym of the latter.

Passaloteuthis cuspidata (Simpson, 1884) (Fig. 12A-D)

Belemnites cuspidatus Simpson, 1884: 50, 250.

Passaloteuthis ima Lang, 1928: 199, pl. 13, fig. 5 (fide Doyle 2010).

Passaloteuthis stonebarroensis Lang, 1928: 200, pl. 13, fig. 6 [fide Doyle 2010].

Belemnites (Passaloteuthis) cuspidatus - Doyle 2003: 161, figs 2C, D.

Passaloteuthis cuspidata - Doyle 2010: 268, pl. 46, figs 1-2.

MATERIAL. - 29 specimens (MNHNL BEL512a-c, BEL514, BEL515a-o, BEL516a-g, BEL527a-c).

StratigraphiCal Distribution. — Pliensbachian, Jamesoni Chronozone up to Margaritatus chronozone. Fresney-le-Puceux: "Marnes à bélemnites" $\mathrm{Mb}$, beds 95-96a.

Geographic distribution. - England, Dorset and Yorkshire (Lang 1928, Doyle 2003, 2010); north-west France, Normandy (this work); possibly also Turkey (Doyle \& Mariotti 1991, recorded as Passaloteuthis aff. ima Lang, 1928).

\section{DESCRIPTION}

The medium sized rostra show a cylindriconical profile and a cylindrical to subhastate outline. The apical region is rather elongated, acute (sometimes "spine-like") and bears two welldeveloped dorsolateral grooves. The lateral lines are especially well-developed in the alveolar region and consist of two parallel running broad depressions. The cross sections are rounded in the stem region, but compressed in the alveolar region. The alveolus occupies approximately $1 / 3$ of the rostrum length.

\section{REMARKS}

The species erected by Simpson (1884) has been revised by Doyle (2003), who figured the type material for the first time and established a synonym list. Passaloteuthis cuspidata differs from $P$. laevigata (Zieten, 1831) by its more compressed cross sections and the more elongated apical region, and the well-developed lateral lines. 


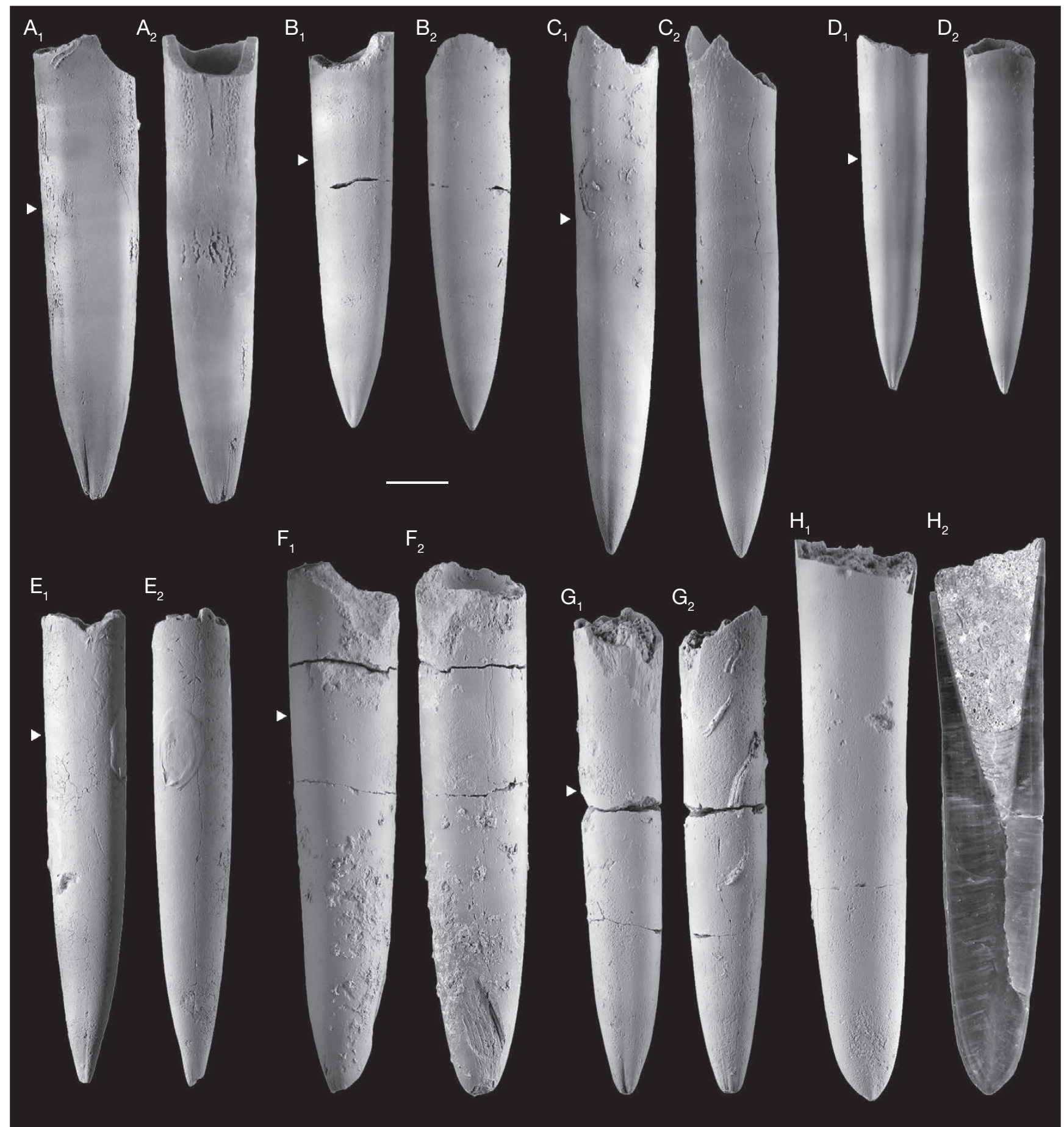

FIG. 12. - Passaloteuthididae (part 3) from the Pliensbachian of Fresney-le-Puceux: A-D, Passaloteuthis cuspidata (Simpson, 1884), A, specimen no. MNHNL BEL512a, bed 95; A1, lateral view, venter right; A2, ventral view, showing an irregular, groove-like incision; B, presumably juvenile/subadult specimen, no. MNHNL BEL512b, bed 95; B1, lateral view, venter right; B2, ventral view; C, specimen with well-developed lateral lines, no. MNHNL BEL514, bed 96a; C1, lateral view, venter right; C2, ventral view; D, possibly juvenile specimen, no. MNHNL BEL527a, bed 95 (base); D1, lateral view, venter right; D2, ventral view; E, Passaloteuthis elongata (Miller, 1826), specimen no. MNHNL BEL505a, bed 95 (base); E1, lateral view, venter right; E2, ventral view; F, G, Passaloteuthis laevigata (Zieten, 1831); F, large specimen with damaged apex and alveolar region in part preserved, no. MNHNL BEL498, bed 98a; F1, lateral view, venter right; F2, ventral view; G, specimen no. MNHNL BEL538, bed 98a; G1, lateral view, venter right; G2, ventral view; H, Parapassaloteuthis sp. A, no. MNHNL BEL501, bed 97b; H1, lateral view, venter left; H2, longitudinal section, lateral view, venter right. Scale bar: $1 \mathrm{~cm}$. White arrows indicate the estimated position of the protoconch.

\section{Passaloteuthis elongata (Miller, 1826) (Fig. 12E)}

Belemnites elongatus Miller, 1826: 60, pl. 7, figs 6-8. — Combémorel et al. $1994: 11$, pl. 2, fig. 1 .

Passaloteuthis argillarum Lang, 1928: 200, pl. 13, fig. 7 (fide Doyle 2010).
Belemnites paxillosus elongatus - Schumann 1974: 23, pl. 2, fig. 14 ; pl. 3, figs 3-5.

Passaloteuthis elongata - Lang 1928: 201, pl. 13, fig. 8. - Rulleau 2007: pl. 41 fig. 3. - Doyle 2010 : 268, pl. 45, figs 14-17 (non fig. 13). - Weis \& Thuy 2015: 107, figs 3B-C. 
MATERIAL. — Three specimen (MNHNL BEL505a-c).

Stratigraphical Distribution. — Lower Pliensbachian, JamesoniDavoei chronozones. Fresney-le-Puceux: "Marnes à bélemnites" Mb, bed 95 (base).

Geographic Distribution. — England, Dorset (Lang 1928, Doyle 2010); north-west Germany (Schumann 1974); Austria, northern Calcareous Alps (Weis \& Thuy 2015); north-west France, Normandy (this work); central France, Mont d'Or Lyonnais (Dumortier 1869; Rulleau 2007), Bulgaria (Stoyanova-Vergilova 1993).

\section{DESCRIPTION}

The medium-sized, moderately slender rostra show a cylindriconical profile and outline. The apical region is elongated and sharply pointed and bears two weakly developed dorsolateral grooves. Lateral lines are indistinct. The cross sections are rounded to slightly compressed $\left(\mathrm{I}_{\mathrm{c}}\right.$ ranging between 1.00 and 1.03; taken at half of the rostrum length). The alveolus occupies approximately $1 / 4$ of the rostrum length.

\section{REMARKS}

The species, insufficiently described by its original author (Miller 1826), has been emended since the designation of a neotype by Lang (1928: 201), and re-illustrated in Doyle (2010: pl. 45, figs 16-17). Passaloteuthis elongata stands morphologically between the slender-elongate passaloteuthid taxa such as $P$. pessula (Simpson, 1884) and the stouter, cylindrical taxa such as $P$. laevigata.

\section{Passaloteuthis laevigata (Zieten, 1831)}

(Fig. 12F-G)

Belemnites laevigatus Zieten, 1831: 29, pl. 21, fig. 12.

Passaloteuthis (Passaloteuthis) paxillosa (sensu Voltz 1830) - Riegraf et al. 1984: 147, pl. 9, figs 3-4, text-figs 43f, 45a, 48a, b (cum syn.).

Passaloteuthis bisulcata - Doyle 1990: 19, pl. 1 figs 1-8; pl. 2, figs 1-4; pl. 3, figs 1-4 (cum syn.). — Schlegelmilch 1998: 51, pl. 2, figs 6-7. - Sanders et al. 2015: 55, figs 5A-B, 7A-E.

Belemnites paxillosus - Combémorel et al. 1994: 9, pl. 1, figs 9, 10.

Passaloteuthis bisulcatus [sic] - Combémorel 1997: pl. 27, fig 9.

Passaloteuthis laevigata - Schlegelmilch 1998: 51, pl. 2, fig. 8. Pinard et al. 2014: 172, fig. 8D. - Weis et al. 2015b: 737, fig. 2i, $\mathrm{j}, \mathrm{k}$ (cum syn.).

Passaloteuthis bruguieriana - Pinard et al. 2014: 172, fig. 8C.

MATERIAL. - Five specimen (MNHNL BEL498, BEL502, BEL522, BEL523, BEL538).

STRATIGRAPHICAL DISTRIBUTION. — Upper Pliensbachian (Margaritatus Chronozone) up to lowermost Toarcian (Tenuicostatum Chronozone). Fresney-le-Puceux: "banc de Roc" Mb, beds 97b, 98a, 98b, 99b, 100.

GeOgraPhic Distribution. - England, Dorset and Yorkshire (Doyle 1990, 2003); Austria, northern Calcareous Alps (Weis \& Thuy 2015); Slovakia (Činčurová 1991); Bulgaria (Stoyanova-Vergilova 1993); south Germany (Riegraf et al. 1984, Schlegelmilch 1998); north-west France, Calvados (Combémorel et al. 1994; this work); north-east France, Lorraine and Luxembourg (R. Weis unpublished field data); Morocco, Rif (Sanders et al. 2015); central France, Mâconnais and
Mont d'Or Lyonnais (Combémorel 1997; Rulleau 2007); Italy, Latium and western Sicily (Weis et al. 2015b).

\section{DESCRIPTION}

The medium- to estimated large-sized, robust rostra shows a cylindrical to cylindriconical profile and a cylindrical or subhastate outline. The apex is rather obtuse and bears two short but well-developed dorsolateral grooves. Especially the ventral side of the apex bears irregular striae. Lateral lines are indistinct. Cross sections are elliptical and only weakly compressed. The alveolus occupies approximately one third to $1 / 4$ of the total rostrum length.

\section{REMARK}

This variable taxon (Doyle 1990 distinguished three "varieties", "Var. A", "Var. B". and "Var. C") has a particularly complex nomenclatural history (see Riegraf et al. 1984 and Doyle 1990). Initially often referred to as "Belemnites paxillosus" (name suppressed by ICZN, see Doyle \& Riegraf 1986) and later Passaloteuthis bruguieriana (d'Orbigny, 1842), respectively Passaloteuthis bisulcata (Blainville, 1827), it has been synonymized by Riegraf et al. (1984), Doyle (1990) and Weis et al. (2015b) with Passaloteuthis laevigata (Zieten, 1831). Other authors (Schlegelmilch 1998; Pinard et al. 2014) consider the latter taxon as a distinct species, a view which is not followed herein. The name given by Blainville (Belemnites bisulcatus Blainville, 1827) would have the priority according to the ICZN, but the type series of Belemnites bisulcatus, partially lost and recently re-investigated by Sanders et al. (2015) presents some nomenclatural issues (Sanders et al. 2015: 55). Pending the nomenclatural status of Belemnites bisulcatus Blainville, 1827, we use here the first valid name, Belemnites laevigatus Zieten, 1831.

\section{Passaloteuthis milleri (Phillips, 1867)}

(Fig. 13A)

Belemnites milleri Phillips, 1867: 54, pl. 8, fig. 19. — Dumortier 1869: 30, pl. 1, figs 1-6.

Passaloteuthis milleri - Doyle 1990: 22, pl. 2, figs 5-9. - StoyanovaVergilova 1993: pl. 22, figs 8-10. — Schlegelmilch 1998: 52, pl. 3, fig. 4; 7, fig. 6. - Pinard et al. 2014: 172, fig. 8E.

MATERIAL. - One specimen (MNHNL BEL493).

Stratigraphical distribution. - Upper Pliensbachian up to lowermost Toarcian (Tenuicostatum Chronozone). Fresney-le-Puceux: "Argiles à poissons" Mb, bed 101.

GeOGRAPHIC Distribution. - England, Yorkshire, Northampton, Dorset (Phillips 1867; Doyle 1990); north-west France, Normandy (this work); central France, Rhône Valley (Dumortier 1869); south France, Causses (Pinard et al. 2014); south Germany, Swabia (Schlegelmilch 1998); Bulgaria (Stoyanova-Vergilova 1993); Luxembourg (R. Weis unpublished field data).

\section{DESCRIPTION}

A single fragmentary rostrum is described, in which the apical and part of the stem regions are preserved. The estimated medium sized rostrum shows a cylindrical or cylindriconical outline and profile. The smooth apex bears only traces of weak and short dorsolateral grooves. The cross section is rounded-subquadrate. 


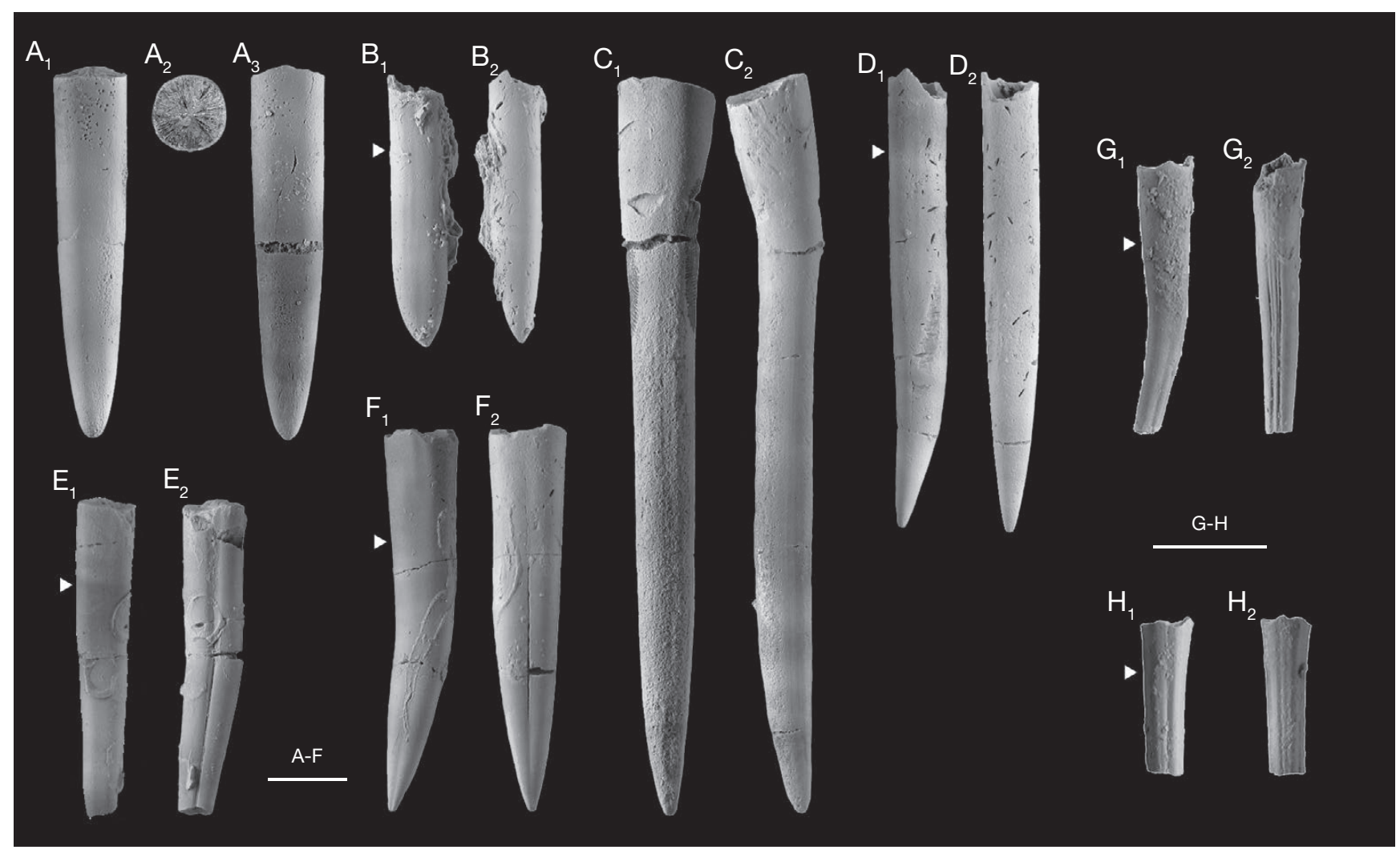

FIG. 13. - Passaloteuthididae (part 4), Salpingoteuthididae and incertae sedis, from the Pliensbachian-Toarcian of Fresney-le-Puceux: A, Passaloteuthis milleri (Phillips, 1867), alveolar part not preserved, specimen no. MNHNL BEL493, bed 101; A1, lateral view, non-orientated; A2, cross section in the stem region; A3, ventral or dorsal view; B, Pleurobelus compressus (Stahl, 1824), specimen with serpulid incrustations, no. MNHNL BEL499, bed 97b; B1, lateral view, venter left; B2, ventral view; C, Pleurobelus lagenaeformis (Hartmann in Zieten, 1832), epirostrum and initial part of orthostrum of a larger specimen, no. MNHNL BEL500, bed 97b; C1, lateral view, non-orientated; C2, ventral or dorsal view; D, Pseudohastites longiformis (Blake in Tate \& Blake, 1876), specimen with numerous borings, no. MNHNL BEL481, bed 99b; D1, lateral view, venter right; D2, ventral view; E, F, Lissajousibelus harleyi (Mayer, 1866); E, specimen with missing apex, no. MNHNL BEL495, bed 102; E1, lateral view, venter right; E2, ventral view; F, specimen no. MNHNL BEL496, bed 99b; F1, lateral view, venter left; F2, ventral view; G, Salpingoteuthis tessoniana (d'Orbigny, 1842), apical part of epirostrum missing, specimen no. MNHNL BEL491a, bed 107; G1, lateral view, venter left; G2, ventral view; H, Salpingoteuthis cf. trisulcata (Blainville, 1827), fragmentary specimen, major part of epirostrum missing, no. MNHNL BEL490, bed 111; H1, lateral view, venter right; H2, ventral view. Scale bars: $1 \mathrm{~cm}$. White arrows indicate the estimated position of the protoconch.

\section{Genus Pleurobelus Naef, 1922}

Type SPECIES. - Belemnites compressus Stahl, 1824 (by original designation), from the upper Pliensbachian of south-west Germany.

Distribution. - Upper Pliensbachian from Europe.

Pleurobelus compressus (Stahl, 1824)

(Fig. 13B)

Belemnites compressus Stahl, 1824: 33.

Pleurobelus compressus - Combémorel et al. 1994: 13, pl. 2, fig. 3. Schlegelmilch 1998: 54, pl. 4, fig. 3. - Pinard et al. 2014: 161, fig. $5 \mathrm{~A}, \mathrm{~B}$.

\section{Material. - One specimen (MNHNL BEL499).}

StratigraphiCAl Distribution. - Upper Pliensbachian, Margaritatus chronozone. Fresney-le-Puceux: "banc de Roc" Mb, bed 97b.

GEOGRAPHIC Distribution. - South Germany (Schlegelmilch 1998); north-west France, Normandy (Combémorel et al. 1994; this work); south France, Causses (Pinard et al. 2014); north-east France, Lorraine (R. Weis unpublished field work); England (Phillips 1866).

\section{DESCRIPTION}

The small sized rostrum possesses a cylindrical outline and profile. The short apex is acute and asymmetrical. A lateral depression is present in the apical region. Triple lateral lines are present. The cross section is compressed $\left(\mathrm{I}_{\mathrm{c}}=1.1\right.$, taken at half of the rostrum length). The alveolus occupies approximately $1 / 3$ to $1 / 4$ of the total rostrum length.

\section{Pleurobelus lagenaeformis (Hartmann in Zieten, 1832)} (Fig. 13C)

Belemnites lagenaeformis Hartmann in Zieten, 1832: 33, pl. 25, fig. 1.

Pleurobelus lagenaeformis - Schlegelmilch 1998: 54, pl. 4, figs 4-6. Pinard et al. 2014: 162, fig 5E-G.

\section{MATERIAL. - One specimen (MNHNL BEL500).}

Stratigraphical distribution. - Upper Pliensbachian, Margaritatus chronozone. Fresney-le-Puceux: "banc de Roc" Mb, bed $97 \mathrm{~b}$.

Geographic distribution. - South Germany (Schlegelmilch 1998); north-west France, Normandy (this work); south France, Causses (Pinard et al. 2014). 


\section{DESCRIPTION}

Only the epirostral part and a fragment of the orthorostrum are preserved. Large sized rostrum (epirostral length $c .75 \mathrm{~mm}$ ). The epirostrum bears two long, lateral depressions and further striae. The cross section of the orthorostrum is subquadrate, compressed $\left(I_{c}=1.15\right)$.

\section{REMARKS}

The epirostral development and the peculiar subquadrate and compressed cross section of the orthorostrum are typical for P. lagenaeformis, as described by Müller-Stoll (1936).

\section{Genus Pseudohastites Naef, 1922}

TyPe SPECIES. - Belemnites scabrosus Simpson, 1866, from the lower Pliensbachian of Robin Hood's Bay, North Yorkshire, England.

Distribution. - Pliensbachian to lowermost Toarcian of Europe, Northern Africa, and Greenland.

Pseudohastites longiformis (Blake in Tate \& Blake, 1876) (Fig. 13D)

Belemnites longiformis Blake in Tate \& Blake, 1876: 320, pl. 4, figs 8a-b.

Belemnites virgatus - Dumortier 1869 (pars): 41, pl. 4, figs 4-6 (fide Doyle 1990: 24).

Pseudohastites longiformis - Doyle 1990: 24, pl. 3 figs 5-9. - Sanders et al. 2015: 57, fig. 7F-G. - Weis et al. 2015b: 738, figs 2h, m.

Material. - One specimen (MNHNL BEL481).

Stratigraphical Distribution. - Uppermost Pliensbachian (Spinatum Chronozone) to lowermost Toarcian (Tenuicostatum Chronozone). Fresney-le-Puceux: "banc de Roc" Mb, bed 99b.

Geographic distribution. - England, Cleveland, Yorkshire (Doyle 1990); north-west France (this work); Mont d'Or Lyonnais (Dumortier 1869); Morocco, Rif (Sanders et al. 2015); Italy, central Apennines (Weis et al. 2015b).

\section{DESCRIPTION}

The small sized, slender rostrum shows a cylindriconical outline and profile. The acute and elongate apical region shows only weak imprints of dorsolateral grooves. Lateral lines are well developed as double shallow depressions. The cross sections are rounded or slightly compressed (in the alveolar region). The alveolus occupies approximately $1 / 6$ of the rostrum length.

\section{Family SALPINGOTEUTHIDIDAE Doyle, 1992}

\section{Genus Salpingoteuthis Lissajous, 1915}

TYPE SPECIES. - Belemnites trisulcatus Blainville, 1827 (by original designation), from the Toarcian of Calvados department, Normandy, north-west France.

Distribution. - Lower Toarcian to lower Aalenian of Europe.
Salpingoteuthis tessoniana (d'Orbigny, 1843)

(Fig. 13G)

Belemnites tessonianus d'Orbigny, 1843: 102, pl. 11, figs 13-18.

Salpingoteuthis tessoniana - Doyle 1992: 70, pl. 28, figs 7-9, 11.Combémorel et al. 1994: 14, pl. 1, figs 11, 12. — Schlegelmilch 1998: 71, pl. 10, figs 9-10.

MATERIAL. - Two specimen (MNHNL BEL491a, b).

STRATIGRAPHICAL DISTRIBUTION. - Lower Toarcian, Bifrons chronozone. Fresney-le-Puceux: "Calcaires et Marnes à Hildoceras" Mbr, bed 107.

Geographic distribution. - North-west France (d'Orbigny 1843; and this work); England (Doyle 1992); less typical records also from south Germany (see remark in Schlegelmilch [1998: 71]).

\section{DESCRIPTION}

The very small sized rostra are conical and have a strongly asymmetrical profile. The rostrum largely consists of a striated epirostrum; striation is strong along the whole ventral side, with four distinct striae which merge into two distinct striae towards the apical end. Striation is present also on the dorsal side, but less strongly developed. Two incised dorsolateral grooves are developed on the epirostrum. Cross sections are subtriangular, compressed in the alveolar region.

\section{Salpingoteuthis cf. trisulcata (Blainville, 1827)}

(Fig. 13H)

cf. Belemnites trisulcatus - Blainville 1827: 83, pl. 5, fig. 13 .

cf. Salpingoteuthis trisulcata - Doyle 1992: 71, pl. 28, figs. 2-5, 10. - Combémorel et al. 1994: 13, pl. 2, figs 12-13. - Schlegelmilch 1998: 70, pl. 10, fig. 1. — Arp 2010: pl. 4, figs 5-6. — Pinard et al. 2014: 173, fig. $8 \mathrm{H}$.

MATERIAL. - One specimen (MNHNL BEL490).

Stratigraphical Distribution. - Upper Toarcian, Pseudoradiosa Chronozone. Fresney-le-Puceux: "Calcaire à grains ferrugineux" $\mathrm{Mb}$, bed 111 .

Geographic distribution. - South Germany (Schlegelmilch 1998; Arp 2010); England, Dorset (Doyle 1992); central-east France, Monts Lyonnais and Isère (Rulleau et al. 1998; Rulleau 2007); south France, Hérault and Aveyron (Rulleau et al. 1998; Pinard et al. 2014); north-west France, Normandy (Blainville 1827; this work).

\section{DESCRIPTION}

Presumably small sized rostrum, with a "trumpet"-like alveolar widening. The well-developed epirostrum bears two long and well-incised dorsolateral grooves and several dorsal and ventral striae.

\section{REMARK}

Despite its fragmentary state of preservation, the studied specimen is tentatively referred to $S$. trisulcata, a well-known and widespread species, whose type material originates from the upper Toarcian of Normandy. 


\begin{tabular}{|c|c|c|c|c|c|c|c|c|c|c|c|}
\hline & \multicolumn{3}{|c|}{ PLIENSBACHIAN } & \multicolumn{8}{|c|}{ TOARCIAN } \\
\hline & $\begin{array}{l}\bar{\Phi} \\
\text { Ð } \\
\text { ○ }\end{array}$ & 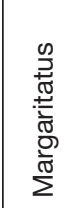 & 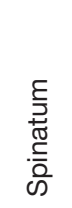 & 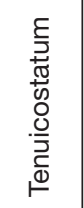 & 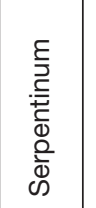 & 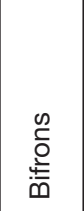 & 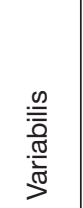 & 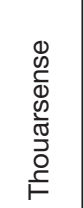 & 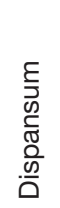 & 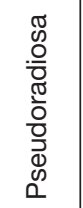 & $\frac{\frac{\infty}{0}}{\frac{D}{\infty}}$ \\
\hline Salpingoteuthis cf. trisulcata (Blainville, 1827) & & & & & & & & & & ??O & $0 ? 0$ \\
\hline Acrocoelites bobeti Lissajous, 1927 & & & & & & & & & & 0 & 0 \\
\hline Hastites subclavatus (Voltz, 1830) & & & & & & & & & & - & \\
\hline Acrocoelites strictus Lissajous, 1927 & & & & & & & 0 & 0 & & & \\
\hline Acrocoelites subgracilis Kolb, 1942 & & & & & & & O & O & & & \\
\hline Acrocoelites cf. triscissus (Janensch, 1902) & & & & & & & O?O & $0 ? 0$ & & & \\
\hline Dactyloteuthis semistriata (Münster, 1830) & & & & & & & 0 & 0 & & & \\
\hline Acrocoelites subtenuis (Simpson, 1855) & & & & & & O & & & & & \\
\hline Acrocoelites riegrafi Doyle, 1992 & & & & & & 0 & & & & & \\
\hline Odontobelus subpyramidalis (Lissajous, 1927) & & & & & & O & & & & & \\
\hline Salpingoteuthis tessoniana (d'Orbigny, 1843) & & & & & & 0 & & & & & \\
\hline Acrocoelites ilminstrensis (Phillips, 1867) & & & & & 0 & & & & & & \\
\hline Lissajousibelus harleyi (Mayer, 1866) & & & & 0 & O?०? & & & & & & \\
\hline Parapassaloteuthis zieteni (Werner, 1912) & & & & $\mathrm{O}$ & & & & & & & \\
\hline Passaloteuthis milleri (Phillips, 1867) & & & & 0 & & & & & & & \\
\hline Pseudohastites longiformis (Blake in Tate \& Blake, 1876) & & & ○ & 0 & & & & & & & \\
\hline Passaloteuthis laevigata (Zieten, 1831) & & 0 & 0 & 0 & & & & & & & \\
\hline Pleurobelus compressus (Stahl, 1824) & & 0 & & & & & & & & & \\
\hline Pleurobelus lagenaeformis (Hartmann in Zieten, 1832) & & 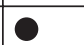 & & & & & & & & & \\
\hline Parapassaloteuthis sp. A & & 0 & & & & & & & & & \\
\hline Passaloteuthis armata (Dumortier, 1869) & & 0 & & & & & & & & & \\
\hline Passaloteuthis cuspidata (Simpson, 1884) & 0 & 0 & & & & & & & & & \\
\hline Passaloteuthis elongata (Miller, 1826) & 0 & & & & & & & & & & \\
\hline Subhastites pseudoclavatus Gustomesov, 1977 & 0 & & & & & & & & & & \\
\hline Subhastites cf. microstylus (Phillips, 1867) & 0 & & & & & & & & & & \\
\hline Gastrobelus umbilicatus (Blainville, 1827) & 0 & & & & & & & & & & \\
\hline
\end{tabular}

FIG. 14. - Stratigraphical distribution of the species studied in Normandy. Species from Fresney-le-Puceux are marked by black dots. Species from Feuguerollessur-Orne (unpublished collection data) are marked by white dots. Question marks refer to uncertain stratigraphic attribution.

Suborder ?BELEMNOPSEINA

Family indet.

Genus Lissajousibelus Weis in Weis et al., 2015

TYPE SPECIES. - Belemnites harleyi Mayer, 1866 (by original designation), from the Toarcian of Calvados department, Normandy, north-west France.

Distribution. - ? Uppermost Pliensbachian to lowermost Toarcian of western France and north-east Spain.

Lissajousibelus harleyi (Mayer, 1866)

(Fig. 13E, F)

Belemnites harleyi Mayer, 1866: 362.

Lissajousibelus harleyi - Weis et al. 2015a: 292, figs 2a-k, 3a-i (cum syn.).
STUDIED MATERIAL. - Three specimen (MNHNL BEL494, BEL495, BEL496).

Stratigraphical Distribution. - ? Uppermost Pliensbachian to lower Toarcian (Tenuicostatum and ?Serpentinum chronozones): Fresney-le-Puceux: "banc de Roc" Mb, bed 99b, and "Argiles à poissons" Fm, beds 101 and 102 .

Geographic Distribution. - North Spain, Asturias (Mouterde 1971); north-west France, Vendée, Sarthe and Calvados (Lissajous 1927; Weis et al. 2015a).

\section{DESCRIPTION}

The small sized rostra show a conical profile and a cylindriconical outline. The acute apex bears two weakly incised dorsolateral grooves. A long and deeply incised ventral groove is present; it displays an intermediate position, fading out both on the apical and the alveolar region without reaching neither the apex nor the alveolar border. Lateral lines are present as broad, shallow depressions on the flanks. The dorsal side of 
the alveolar region is flattened. Cross sections of the rostrum are overall depressed $\left(I_{c}\right.$ taken at half of the rostrum length corresponding to 0.87 and 0.91 respectively). The alveolus occupies approximately $1 / 3$ of the total rostrum length.

\section{REMARKS}

The species has recently been described in detail by Weis et al. (2015a), based on abundant material from Feuguerolles-surOrne, a section near Fresney-le-Puceux. The material collected in Fresney is complementary to this study and confirms the stratigraphic range of L. harleyi (Weis et al. 2015a).

\section{LOWER JURASSIC BELEMNITE DIVERSITY IN NORMANDY COMPARED TO WESTERN AND CENTRAL EUROPEAN BELEMNITE FAUNAS}

The studied outcrop in Fresney-le-Puceux allows a rather unique insight into the diversity of the belemnite assemblages of a single locality with belemnites recorded from 10 out of the 13 identified chronozones. Together with a largely unpublished collection (reported herein as preliminary results; Figs 14, 15) from the nearby locality of Feuguerolles-sur-Orne (Weis et al. 2015a), we consider these data as a representative taxonomic record for the Pliensbachian-Toarcian interval in the western part of the Paris Basin. The data from Normandy will be included in a comprehensive work on the paleobiogeography and taxonomic diversity of European Lower Jurassic belemnites.

\section{LOWER PliensbaChian (DAVOEI CHRONOZONE)}

The "Marnes à bélemnites" Member yields large quantities of belemnites of which most rostra belong to the Passaloteuthididae, especially Passaloteuthis, well represented by rather robust and conical morphologies. Numerous specimens are also attributed to Gastrobelus umbilicatus. Only rare specimens, mostly preserved as fragments owing to their thin and small rostrum, can be attributed to the hastitid genus Subhastites.

The most diversified faunas from the lower Pliensbachian have been described from England (Dorset: Lang 1928, revised in Doyle 2010), from north Germany (Schumann 1974) and from south Germany (Swabia: summarized in Riegraf 1980 and Schlegelmilch 1998). Other, more scattereds and often less-well stratigraphically constrained faunas are known from central France (Dumortier 1869), from Turkey (Doyle \& Mariotti 1991), from the northern Calcareous Alps (Weis \& Thuy 2015) and the Pienniny Klippenbelt (Činčurová 1974, 1975) and Bulgaria (summarized in Stoyanova-Vergilova 1993). They all present a similar composition, at least at generic level (Doyle 1994; Weis \& Thuy 2015).

\section{UPPER PLIENSBACHIAN (MARGARITATUS AND SPINATUM CHRONOZONES)}

The "banc de Roc" Member yields numerous belemnites, but the carbonaceous nature of the embedding rock strongly hampers collecting them in greater numbers. Passaloteuthidids of the genera Passaloteuthis, Pleurobelus, and Pseudohastites are dominant.
At a European scale, the belemnite faunas of the upper Pliensbachian, in contrast to the better known and more diverse faunas from lower Pliensbachian and Toarcian (see also Dera et al. 2016), are not very well known, as there is no monographic treatment of them, so far. Under these circumstances, the most significant data in this respect are from the south of Germany (Swabia: Riegraf 1980; Schlegelmilch 1998). Other occurrences comprise Central Italy (Weis et al. 2015b), Bulgaria (summarized in Stoyanova-Vergilova 1993), and the south of France (Pinard et al. 2014). They all show strong similarities in taxonomic composition, comprising several species assigned to Passaloteuthis and other passaloteuthid genera (Pleurobelus, Gastrobelus). Only the upper Pliensbachian of central Italy yields some rare, peculiar forms with alveolar grooves (Weis et al. 2015b), that have not yet been found elsewhere.

\section{LOWER TOARCIAN (TENUICOSTATUM-BIFRONS CHRONOZONES)}

The lower Toarcian belemnite record in Fresney-le-Puceux is rather meagre, due to the calcareous nature of the "Couche à Tenuicostatum" Fm and the strongly reduced thickness of the "Argiles à poissons" Fm. The latter units contain numerous, but poorly diversified passaloteuthids and acrocoelitids. The presence of Lissajousibelus harleyi, a peculiar belemnite with an intermediate ventral canal is a remarkable feature of the lowermost Toarcian (Tenuicostatum Chronozone) assemblages in Normandy (Weis et al. 2015a). This taxon has not been found yet in coeval and well-studied assemblages of England and the south of Germany.

The "Calcaires et Marnes à Hildoceras" Member (Bifrons Zone) yielded relatively few belemnite rostra, indicating low diversity (Acrocoelites spp. and the dwarfed Salpingoteuthis tessoniana, which is known also from England (Doyle 1992) and Swabia (Schlegelmilch 1998)). Belemnite faunas from the Bifrons Zone are more diverse in England (Doyle 1990, 1992) and south Germany (Riegraf 1980). The relatively low species diversity in Fresney-le-Puceux needs further investigation as it might be caused by collection bias, given the apparent absence of sediment from the upper part of the Bifrons zone (Bifrons subzone).

The second-order crisis of the Pliensbachian-Toarcian (i.e. the early Toarcian crisis) affects many marine taxa (see Neige et al. 2013), and has been shown to be a two-pulses phenomenon (Dera et al. 2010, 2011): one at the Pliensbachian-Toarcian boundary (i.e. Spinatum-Tenuicostatum chronozones boundary), and the other in the Early Toarcian, at the Tenuicostatum-Serpentinum chronozones boundary. However, apparently belemnite data from Fresneyle-Puceux, or complementary data from Feuguerolles-sur Orne, do not exactly follow this scheme (Fig. 15): whereas the Tenuicostatum-Serpentinum boundary clearly shows a decrease of species numbers, the Pliensbachian-Toarcian boundary is apparently marked by an increase of belemnites species. Further date are needed to substantiate this seemingly paradoxical trend. 


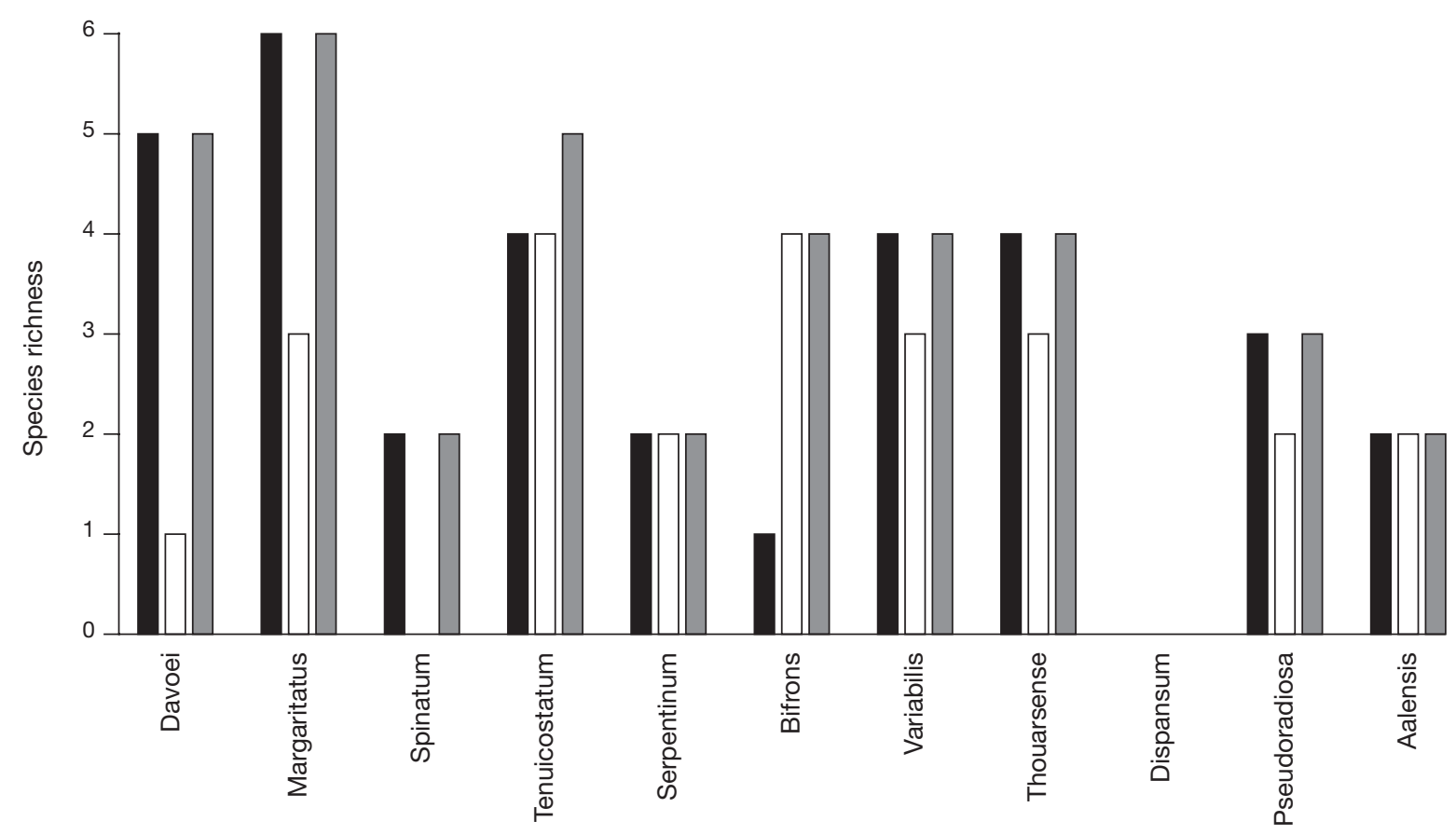

FIG. 15. - Species richness throughout the studied period. Black bars, Fresney-le-Puceux; white bars, Feuguerolles-sur Orne (unpublished collection data); grey bars, total number of species from Normandy (Fresney-le-Puceux and Feuguerolles-sur-Orne).

\section{UPPER TOARCIAN (VARIABILIS-AALENSIS CHRONOZONES)}

The "Marnes à Haugia" Member and the subsequent "Calcaires à Grammoceras" and "Calcaires à grains ferrugineux" members are particularly rich in belemnite specimens, although most specimens belong to Acrocoelites strictus and Acrocoelites bobeti. Other species of Acrocoelites and other genera (Dactyloteuthis, Hastites, Salpingoteuthis) are far less represented in absolute numbers.

Belemnite faunas from the upper Toarcian have also been described from many areas of western and central Europe including England (revised by Doyle 1990, 1992), south Germany (summarized in Schlegelmilch 1998), south France (Causses: Pinard et al. 2014), Luxembourg (Weis 1999), central-east France (Monts Lyonnais and Isère: revision in Rulleau 2007), Slovakia (e.g. Činčurová 1983), Bulgaria (summarized in Stoyanova-Vergilova 1993). In the south of Germany, belemnites reach a diversity peak during the uppermost Toarcian (Pseudoradiosa-Aalensis chronozones: Dera et al. 2016). However, in the south France, diversity is relatively low in the uppermost Toarcian with a poorly diversified acrocoelitid fauna and apparently "Tethyan" elements (Salpingoteuthis and Rhabdobelus) (Doyle 1994). Based on our data from Fresney-le-Puceux and Feuguerolles-sur-Orne (Fig. 15), a low diversity for the uppermost Toarcian can be recognized also in Normandy, with the presence of Acrocoelites bobeti, Acrocoelites spp., Hastites subclavatus, and Salpingoteuthis trisulcata.

\section{Acknowledgements}

Marc Chesnier (Cresserons, Calvados) allowed the study of his remarkable belemnite collection from Feuguerolles-sur-Orne (Calvados, France), used herein as comparative material. Paul Braun (MNHNL) assisted with the processing of the photo- graphs. Jo Simon, Guy Kronz and Paul Braun (all MNHNL) are acknowledged for technical support during the cleaning process of the specimens. The management of the "Société des carrières de la Roche Blain" is thanked for their permission to take samples for study at the Fresney quarry. We are particularly grateful to Peter Doyle and a second anonymous reviewer for their constructive remarks. This work was carried out as part of the project "The Pliensbachian-Toarcian perturbations and their legacy in marine biodiversity of the Western Tethys" by the Natural History Museum Luxembourg. This publication was supported by INSU Intervie (PN), and is a contribution by the SAMBA team of the Biogeosciences laboratory (Dijon, France).

\section{REFERENCES}

ARP G. 2010. - Ammonitenfauna und Stratigraphie des Grenzbereichs Jurensismergel/Opalinuston-Formation bei Neumarkt i.d. Opf. (oberstes Toarcium, Fränkische Alb). Zitteliana A50: 25-54.

Blainville M. H. DuCROTAY DE 1827. — Mémoire sur les bélemnites, considérées zoologiquement et géologiquement. Levrault, Paris/Strasbourg, 136 p. https://doi.org/10.5962/bhl.title. 45666 ČInČUROVÁ E. 1974. - Neue Belemniten Arten aus dem Lias der Podbielischen Entwicklung. Annotationes Zoologicae et Botanicae, Slovenské národné múzeum 95: 1-5.

ČINČUROVÁ E. 1975. — Nové nálezy Belemnitov v Liase Západných Karpát [Neue Belemniten-Funde im Lias der Westkarpaten]. Acta Rerum Naturalium Muzei Nationalis Slovenici 21: 43-53. (in Slovak with German abstract).

ČInČUROVÁ E. 1983. - Upper Liassic belemnites from the Manin Unit near Tunezice (CSSR). Acta Rerum Naturalium Muzei Nationalis Slovenici 29: 3-65 (in Slovak with English summary).

ČInČUROVÁ E. 1989. - Passaloteuthis tunezicensis sp. n. (Belemnitidae) - eine neue Art aus den slowakischen Westkarpaten. Zborník Slovenského Národného Múzea Prírodné Vedy 35: 3-5 (in German, with Slovakian abstract). 
ČInČUROVÁ E. 1991. — Beitrag zur Kenntnis der Belemniten der Slowakei VI. Zborník Slovenského Národného Múzea Prírodné Vedy 37: 3-12 (in Slovak, with German abstract).

Combémorel R. 1971. - Figuration et complément de diagnose de Acrocoelites bobeti Lissajous, bélemnite du Lias supérieur français. Geobios 4 (1): 61-68. https://doi.org/10.1016/S00166995(71)80007-4

Combémorel R. 1997. - Bélemnites, in Cariou E. \& HantzPerGUE P. (ed.), Biostratigraphie du Jurassique ouest-européen et méditerranéen: zonations parallèles et distribution des invertébrés et microfossiles. Bulletin des Centres de Recherches ExplorationProduction Elf-Aquitaine, Mémoire 17: 157-167.

Combémorel R., Fischer J.-C. \& Rioult M. 1994. — Bélemnites, in FIsCHER J.-C. (ed.), Révision critique de la Paléontologie française d'Alcide d'Orbigny. Vol. I. Coléö̈des. Mason, Paris: 8-22.

DelSATE D. \& WeIs R. 2010. — La Couche à Crassum (Toarcien moyen) au Luxembourg: stratigraphie et faunes de la coupe de Dudelange-Zoufftgen, in WeIs R. \& GuÉRIN-FraniatTe S. (eds), Le Jurassique inférieur et moyen au Luxembourg. Nouvelles données paléontologiques et biostratigraphiques. Ferrantia 62: 19-34.

Dera G., Neige P., Dommergues J.-L., Fara E., Laffont R. \& Pellenard P. 2010. - High resolution dynamics of Early Jurassic marine extinctions: the case of Pliensbachian-Toarcian ammonites (Cephalopoda). Journal of the Geological Society 167: 21-33. https://doi.org/10.1144/0016-76492009-068

Dera G., Neige P., Dommergues J.-L. \& Brayard A. 2011. Ammonite paleobiogeography during the Pliensbachian-Toarcian crisis (Early Jurassic) reflecting paleoclimate, eustasy, and extinctions. Global and Planetary Change 78: 92-105. https:// doi.org/10.1016/j.gloplacha.2011.05.009

Dera G., Toumoulin A. \& De Baets K. 2016. - Diversity and morphological evolution of Jurassic belemnites from South Germany. Palaeogeography, Palaeoclimatology, Palaeoecology 457: 80-97. https://doi.org/10.1016/j.palaeo.2016.05.029

Dommergues J.-L., Meister C. \& Mouterde R. 1997. — Pliensbachian, in CARIOU E. \& HANTZPERGUE P. (eds), Biostratigraphie du Jurassique ouest-européen et méditerranéen. Bulletin des Centres de Recherches Exploration-Production Elf-Aquitaine, Mémoire 17: 15-24.

Dommergues J.-L., Dugué O., Gauthier H., Meister C., Neige P., RaYnaud D., SAVARY X. \& Trévisan M. 2008. — Les ammonites du Pliensbachien et du Toarcien basal dans la carrière de la Roche Blain (Fresnay-le-Puceux, Calvados, Basse-Normandie, France). Taxonomie, implications stratigraphiques et paléobiogéographiques. Revue de Paléobiologie 27 (1): 265-329.

Douvillé M. 1879. - Atlas du IVe volume de l'Explication de la Carte géologique de la France. Bulletin de la Société géologique de France, 3ème série, 7: 91, 92

DoyLE P. 1990. — The British Toarcian (Lower Jurassic) belemnites, Part 1. Monograph of the Palaeontographical Society 144: 1-49.

DoyLE P. 1992. - The British Toarcian (Lower Jurassic) belemnites, Part 2. Monograph of the Palaeontographical Society 145: 50-79.

DOYLE P. 1994. - Aspects of the distribution of Early Jurassic belemnites. Palaeopelagos, Special Publication 1: 109-120.

Doyle P. 2003. - Type belemnites of Simpson's Fossils of the Yorkshire Lias. Proceedings of the Yorkshire Geological Society 54 (3): 147-184. https://doi.org/10.1144/pygs.54.3.147

DoYLE P. 2010. - Mollusca, Belemnites, in LORD A. R. \& DAVIS P. G. (eds), Fossils from the Lower Lias of the Dorset Coast. Field Guides to Fossils. Vol. 13. The Palaeontological Association, London: 262-275. http://go.palass.org/66r

DOYLE P. \& RIEGRAF W. 1986. — Belemnites paxillosa Lamarck Proposed suppression of both generic and specific names. Z.N.(S.) 2571. Bulletin of Zoological Nomenclature 43: 355-359. https:// doi.org/10.5962/bhl.part.468

Doyle P. \& Kelly S. R. A. 1988. - The Jurassic and Cretaceous belemnites of Kong Karls Land, Svalbard. Skrifter Norsk Polarinstitutt 189: 1-77. http://hdl.handle.net/11250/173544

Doyle P. \& MARIOTTI N. 1991. — Jurassic and Lower Cretaceous belemnites from northwestern Anatolia (Turkey). Geologica Romana 27: 347-379.

Dugué O., Fily G. \& Rioult M. 1998. — Le Jurassique des Côtes du Calvados. Biostratigraphie, sédimentologie, paléoécologie, paléogéographie et stratigraphie séquentielle. Bulletin trimestriel de la Société géologique de Normandie et des Amis du Muséum du Havre 85: 1-132.

Dumortier E. 1869. - Études paléontologiques sur les dépôts jurassiques du Bassin du Rhône. Troisième partie: Lias moyen. Savy, Paris, 348 p.

Elmi S., Rulleau L., Gabilly J. \& Mouterde R. 1997. — Toarcien, in CARIOU E. \& HANTZPERGUE P. (ed.), Biostratigraphie du Jurassique ouest-européen et méditerranéen: zonations parallèles et distribution des invertébrés et microfossiles. Bulletin des Centres de Recherches Exploration-Production Elf-Aquitaine, Mémoire 17: 25-36.

EUDES-DESLONGCHAMPS E. 1865. —Études sur les étages jurassiques inférieurs de la Normandie. Mémoires de la Société linnéenne de Normandie 14 (for 1863-1864): 1-296.

Gustomesov V. A. 1977. - For revision of the Jurassic belemnites. Byulleten Moskovskogo Obshchestva Ispytatelei Prirody, otdel geologicheskii (Bulletin of Moscow Society of Naturalists, Geological Section) 52 (2): 103-117 (in Russian).

HOWARTH M. K. 1992. - The ammonite family Hildoceratidae in the Lower Jurassic of Britain. Monograph of the Palaeontographical Society 145-146: 1-200.

JANENSCH W. 1902. — Die Jurensis-Schichten des Elsass. Abhandlungen zur geologischen Spezialkarte Elsass-Lothringens, Neue Folge 5: 1-151.

KolB H. 1942. - Die Belemniten des jüngeren Lias z in Nordbayern. Zeitschrift der Deutschen Geologischen Gesellschaft 94: 145-168.

LANG W. D. 1928. — Part IV. Belemnites, in LaNG W. D., SpATH L. F., Cox L. R. \& Muir-Wood H. M. (eds), The Belemnite Marls of Charmouth. A series in the Lias of the Dorset Coast. Quarterly Journal of the Geological Society 84 (2): 196-221. https:// doi.org/10.1144/GSL.JGS.1928.084.01-04.06

Lissajous M. 1906. - Toarcien des environs de Mâcon. Protat Frères, Mâcon, 56 p.

LisSAJOUS M. 1925. - Répertoire alphabétique des bélemnites jurassiques précédé d'un essai de classification. Travaux du Laboratoire de Géologie de la Faculté des Sciences de Lyon 8 (7): 1-173.

Lissajous M. 1927. - Description de quelques nouvelles espèces de bélemnites jurassiques. Travaux du Laboratoire de Géologie de la Faculté des Sciences de Lyon 10 (7): 1-42.

MAYER K. 1866. - Diagnoses de bélemnites nouvelles. Journal de Conchylogie 3 (6): 358-369. https://biodiversitylibrary.org/ page/15667596

MiLLER J. S. 1826. - Observations on belemnites. Transactions of the Geological Society of London 1: 45-62. https://doi.org/10.1144/ transgslb.2.1.45

Mouterde R. 1971. - Une coupe du Lias à Obon aux confins des Provinces de Teruel et de Saragosse. Cuadernos de Geologia Iberica 2: 345-354.

MÜller-STOLl H. 1936. - Beiträge zur Anatomie der Belemnoidea. Nova Acta Leopoldina, Neue Folge 4: 160-226.

MÜNSTER G. GRAF ZU 1830. — Bemerkungen zur näheren Kenntnis der Belemniten. Birner, Bayreuth, 18 p.

NAEF A. 1922. - Die fossilen Tintenfische. G. Fischer, Jena, 322 p.

Neige P., Dera G. \& Dommergues J.-L. 2013. - Adaptive radiation in the fossil record: a case study among Jurassic ammonoids. Palaeontology 56: 1247-1261. https://doi. org/10.1111/pala.12062

Orbigny A. D. D' 1842-51. - Paléontologie française. Description zoologique et géologique de tous les animaux mollusques et rayonnés fossiles de France, comprenant leur application a la connaissance de couches, in Terrains Oolitiques ou Jurassiques 1: 1-80 (1842), 81-192 (1843), 193-312 (1844), 313-368 (1845), 369-432 (1846), 433-464 (1847), 465-504 (1848), 505-520 (1849), 521632 (1850), 633-642 (1851). A. D. d'Orbigny, Paris. https:// doi.org/10.5962/bhl.title.50510 
PAGE K. N. 2003. — The Lower Jurassic of Europe: its subdivision and correlation, in INESON J. R. \& SURLYK F. (eds), The Jurassic of Denmark and Greenland. Geological Survey of Denmark and Greenland Bulletin 1: 23-59.

Phillips J. 1865. — A monograph of British Jurassic Belemnitidae. Part 2. Monograph of the Palaeontographical Society 17 (74): 1-28. https://www.biodiversitylibrary.org/bibliography/53522

PhILLIPS J. 1866. - A monograph of British Jurassic Belemnitidae. Part 3. Monograph of the Palaeontographical Society 18 (78): 29-52. https://www.biodiversitylibrary.org/bibliography/53522

PHILliPS J. 1867. — A monograph of British Jurassic Belemnitidae. Part 4. Monograph of the Palaeontographical Society 20 (88): 53-88. https://www.biodiversitylibrary.org/bibliography/53522

Pinard J.-D., Weis R., Neige P., Mariotti N. \& Di Cencio A. 2014. - Belemnites from the Upper Pliensbachian and the Toarcian (Lower Jurassic) of Tournadous (Causses, France). Neues Jahrbuch für Geologie und Paläontologie, Abhandlungen 273 (2): 155-177. https://dx.doi.org/10.1127/0077-7749/2014/0421

Quenstedt F. A. 1845-1849. - Petrefaktenkunde Deutschlands. Cephalopoden. Fues, Tübingen, 580 p. https://doi.org/10.5962/ bhl.title. 85310

RiegraF W. 1980. - Revision der Belemniten des Schwäbischen Jura. Teil 7. Palaeontographica (A) 169: 128-209.

RIEGRAF W. 2000. - The belemnites described by Baron Ernst Friedrich von Schlotheim (1764-1833). Paläontologische Zeitschrift 74 (3): 281-303.

Riegraf W., Werner G. \& LÖRCHER F. 1984. — Der Posidonienschiefer, Biostratigraphie, Fauna und Fazies des südwestdeutschen Untertoarciums (Lias epsilon). Enke, Stuttgart, 195 p.

Riegraf W., JANSSEN N. \& SCHMITT-RIEgRAF C. 1998. — Cephalopoda dibranchiata fossiles (Coleoidea) II, in WestPHAL F. (ed.), Fossilium Catalogus Animalia, vol. 135. Backhuys Publishers, Leiden, $519 \mathrm{p}$.

Rioult M. 1964. - Le stratotype du Bajocien. Colloque du Jurassique à Luxembourg, 1962. Comptes rendus et Mémoires de l'Institut Grand Ducal du Luxembourg, Section des Sciences naturelles, physiques et mathématiques: 239-258.

Rioult M. 1968. - Contribution à l'étude du Lias de la bordure occidentale du Bassin de Paris. PhD Thesis, Université de Caen, 585 p. (unpublished).

Rioult M. 1971. - Observations sur le stratotype du Bajocien et sur l'étage bajocien de A. d'Orbigny. Colloque du Jurassique à Luxembourg, 1967. Mémoires du Bureau de recherches géologiques et minières 75: 375-383.

Rioult M. 1980. - Maine, Perche, Normandie, in DebrandPassard S., Enay R. \& Rioult M. (eds), Synthèse géologique du Bassin de Paris, chapitre Jurassique. Mémoires du Bureau de recherches géologiques et minières 101: 214-216.

RULLEAU L. 2007. - Biostratigraphie et paléonologie de la région lyonnaise. Tome II: du socle au Lias moyen. Section Géologie et Paléontologie du Comité d'entreprise Lafarge Ciments, Lozanne, 229 p.

Rulleau l., Alméras Y., Combémorel R., Elmi S. \& TintanT H. 1998. - Révision critique des céphalopodes et des brachiopodes décrits dans le tome IV (Toarcien, Aalénien) des «Études paléontologiques des dépôts jurassiques du Bassin du Rhône", par Eugène Dumortier (1874). Mémoires du Muséum d'Histoire naturelle de Lyon 2: 1-208.

SACHS V. N. \& NALnjaeVA T. I. 1970. - Early and Middle Jurassic Belemnites of the Northern USSR. Nannobelinae, Passaloteuthinae and Hastitidae. Nauka, Leningrad, 228 p. (in Russian).

SANDERS M. T., BARDin J., BenZZAGAGH M. \& CECCA F. 2015. — Early Toarcian (Jurassic) belemnites from northeastern Gondwana (South Riffian ridges, Morocco). Paläontologische Zeitschrift 89 (1): 51-62.

SCHLEGELMILCH R. 1998. - Die Belemniten des süddeutschen Jura: ein Bestimmungsbuch für Geowissenschaftler und Sammler. Gustav Fischer, Stuttgart/Jena, $151 \mathrm{p}$.

SCHUMANN H. O. 1974. - Die Belemniten des norddeutschen Lias gamma. Geologisches Jahrbuch, Reihe A (1974): 1-85.
SChWegler E. 1962. — Revision der Belemniten des Schwäbischen Jura. Teil 3. Palaeontographica (A) 120: 121-164.

SCHWEgLER E. 1965. - Die Belemniten des Schwäbischen Jura. Teil 4. Palaeontographica (A) 124: 75-115.

SCHWegler E. 1971. - Revision der Belemniten des Schwäbischen Jura. Teil 6. Palaeontographica (A) 138: 81-129.

Simpson M. 1855. - The Fossils of the Yorkshire Lias; Described from Nature. $1^{\text {st }}$ edition, Whittaker, London and Whitby, $149 \mathrm{p}$.

SiMPSON M. 1884. - The Fossils of the Yorkshire Lias; Described from Nature. $2^{\text {nd }}$ edition. Wheldon, London and Whitby, 256 p.

STAHL C. F. 1824. - Übersicht über die Versteinerungen Württembergs. Korrespondenzblatt des Württembergischen Landwirtschaftlichen Vereins 6: 1-91.

Stoyanova-Vergilova M. 1993. - Les fossiles de Bulgarie. IIIa. Jurassique. Belemnitida. Académie Bulgare des Sciences, Sofia, 212 p. (in Bulgarian with French summary).

STURZ I. 1958. - Die Belemniten des mittleren und oberen Lias zeta Nordwestdeutschlands (Striatulus- bis Aalensis Zone). Inaugural-Dissertation zur Erlangung des Doktorgrades der Hohen Philosophischen Fakultät der Christian-Albrechts Universität, Kiel, 131 p. (unpublished thesis)

STURZ-KÖWING I. 1960. - Variationsstatistische Untersuchungen an Belemniten des Lias zeta. Meyniana 9: 1-12.

TATE R. \& BlaKe J. F. 1876. - The Yorkshire Lias. Van Voorst, London, 475 p.

Thierry J. \& BARrier E. 2000. - Middle Toarcian, in DerCourT J., Gaetani M., VRielynck B., Barrier E., Biju-Duval B., BrUNet M. F., Cadet J. P., Crasquin S. \& Sandulescu M. (eds), Atlas of Peri-Tethys, Paleogeographical Maps. Commission for the Geological Map of the World, Paris: 9.

Vernhet Y., Maurizot P., Le Gall J., Gigot P., Dupret L., Lerouge G., BesOMBES J.C., BARBIER G. \& PAYT., WITH THE COllabORATION of Pellerini J., Dugué O. \& Fily G. 2002. - Notice explicative, Carte géologique de la France à 1/50000, feuille Villiers-Bocage (145). Bureau de Recherches géologiques et minières, Orléans, 229 p.

Voltz P. L. 1830. - Observations sur les bélemnites. Mémoires de la Société d'Histoire naturelle de Strasbourg 1 (I-IV): 1-70. https:// biodiversitylibrary.org/page/33963291

WeIS R. 1999. - Die Belemniten der Minette-Formation (ob. Toarcium - ob. Aalenium) Luxemburgs, in Delsate D., DufFIN C. \& WEIS R. (eds), Les collections paléontologiques du Musée national d'histoire naturelle de Luxembourg. Fossiles du Trias et du Jurassique. Travaux scientifiques du Musée national d'histoire naturelle de Luxembourg 32: 207-246.

WeIs R. \& ThuY B. 2015. - A Sinemurian-Pliensbachian belemnite assemblage from the Glasenbach Gorge (Northern Calcareous Alps, Austria). Annalen des Naturbistorischen Museums, Wien, Serie A 117: 101-114. http://www.jstor.org/stable/43923084

Weis R., Dzyuba O. S., Mariotti N. \& Chesnier M. 2015a. - Lissajousibelus nov. gen., an Early Jurassic "canaliculate" belemnite from Normandy, France. Swiss Journal of Palaeontology 134 (2): 289-300.

Weis R., Mariotti N. \& Di CenCio A. 2015b. - Systematics and evolutionary implications of Early Jurassic belemnites from the Peri-Mediterranean Tethys. Paläontologische Zeitschrift 89 (4): 729-747.

Werner E. 1912. — Über die Belemniten des schwäbischen Lias und die mit ihnen verwandten Formen des Braunjura (Acoeli). Palaeontographica 59: 103-143. https://biodiversitylibrary.org/page/35881649

ZIETEN C. H. VON. 1830-1833. — Die Versteinerungen Württembergs oder naturgetreue Abbildungen der in den vollständigsten Sammlungen, namentlich der in dem Kabinett des Oberamts-Arzt D. Hartmann befindlichen Petrefacten, mit Angabe der Gebirgs-Formationen, in welchen dieselben vorkommen und der Fundorte. Expedition des Werkes unserer Zeit, Stuttgart, 102 p.

Submitted on 12 May 2017; accepted on 3 October 2017; published on 1 March 2018. 